\title{
Non-Coding RNAs in Lung Tumor Initiation and Progression
}

\author{
Ruben Mercado Santos ${ }^{\dagger}$, Cerena Moreno ${ }^{\dagger}(\mathbb{C})$ and Wen Cai Zhang * ${ }^{*}$ \\ Department of Cancer Division, Burnett School of Biomedical Sciences, College of Medicine, University of \\ Central Florida, 6900 Lake Nona Blvd, Orlando, FL 32827, USA; ruben.mercado30@Knights.ucf.edu (R.M.S.); \\ cerenamoreno@Knights.ucf.edu (C.M.) \\ * Correspondence: wencai.zhang@ucf.edu; Tel.: +1-407-266-7178 \\ + These authors contributed equally to this work.
}

Received: 14 March 2020; Accepted: 14 April 2020; Published: 16 April 2020

\begin{abstract}
Lung cancer is one of the deadliest forms of cancer affecting society today. Non-coding RNAs, such as microRNAs (miRNAs), long non-coding RNAs (lncRNAs), and circular RNAs (circRNAs), through the transcriptional, post-transcriptional, and epigenetic changes they impose, have been found to be dysregulated to affect lung cancer tumorigenesis and metastasis. This review will briefly summarize hallmarks involved in lung cancer initiation and progression. For initiation, these hallmarks include tumor initiating cells, immortalization, activation of oncogenes and inactivation of tumor suppressors. Hallmarks involved in lung cancer progression include metastasis and drug tolerance and resistance. The targeting of these hallmarks with non-coding RNAs can affect vital metabolic and cell signaling pathways, which as a result can potentially have a role in cancerous and pathological processes. By further understanding non-coding RNAs, researchers can work towards diagnoses and treatments to improve early detection and clinical response.
\end{abstract}

Keywords: microRNA; long non-coding RNA; lung cancer; immortalization; tumor initiation; tumor progression; cancer metabolism; oncogene; RNA editing; RNA modifications

\section{Introduction}

Lung cancer continues to be one of the leading causes of cancer death worldwide [1,2]. In the United States alone, it is estimated that 228,820 people will be diagnosed with lung cancer in the year 2020 and that 135,720 individuals will die from lung cancer [2,3]. Although the average 5-year survival rate of patients with lung cancer has increased from 14\% (1989-1995) [4] to 19\% (2009-2015) [2] among patients in the United States during last two decades, further research is being conducted to increase the long-term survival of these patients. Non-coding RNAs have become an area of interest, as their expression is altered in specific cancers, hence implicating them as possible controllers of tumor initiation [5] and progression [6]. This review will briefly summarize hallmarks involved in lung tumorigenesis and metastasis and then specifically focus on microRNAs (miRNAs), long non-coding RNAs (lncRNAs), and circular RNAs (circRNAs) that have been found to be dysregulated in lung tumors. This can occur through different mechanisms of action in affecting the aforementioned hallmarks. Furthermore, technologies currently being developed to further strengthen our understanding of non-coding RNAs will be discussed. At last, the therapeutic value of targeting these non-coding RNAs will be evaluated.

\section{Lung Cancer}

Lung cancer is divided into two main categories: Non-small cell lung carcinoma (NSCLC), which currently accounts for $85 \%$ of new lung cancer diagnoses and small-cell lung carcinoma 
(SCLC), which accounts for $15 \%$ of lung cancer diagnoses [7]. NSCLC is further divided into three different forms, including adenocarcinoma, squamous-cell carcinoma, and large-cell carcinoma [7]. The reasoning behind these divides is due to histopathological and clinical differences [8]. For instance, in regard to genetic mutations, the main causes of continued proliferation of adenocarcinoma, squamous-cell carcinoma, and SCLC differ. This is shown by the observance that adenocarcinoma is commonly caused by liver kinase B1 (STK11) mutations, epidermal growth factor receptor (EGFR) kinase domain mutations, tyrosine-protein kinase MET (MET) amplification, Kirsten rat sarcoma viral (KRAS) mutations, and anaplastic lymphoma kinase (ALK) mutations. Alternatively, squamous-cell carcinoma is commonly caused by EGFR amplification, phosphatidylinositol-4,5-bisphosphate 3-kinase catalytic subunit alpha (PIK3CA) amplification and MET amplification [7]. In addition, SCLC is commonly caused by MET mutations and PIK3CA amplification [7]. Yet, other abnormalities such as tumor protein p53 (TP53) mutations are highly found throughout all the aforementioned types of lung cancers [9]. Other characteristics shared by the different types and subtypes of lung cancer are the different factors linked to their onset such as non-genetic abnormalities including smoking behaviors, exposure to radon gas, asbestos, radiation, air pollution and diesel exhaust [8] along with individual-based factors such as aging, obesity, lack of physical activity and reproductive changes $[1,10]$. Patients with extensive-stage SCLC typically undergo immunotherapy in combination with chemotherapy [11,12], while patients with NSCLC typically receive treatment options such as chemotherapy, immunotherapy, and targeted therapy drugs such as EGFR and anaplastic lymphoma kinase (ALK) inhibitors [13]. Different from other receptor tyrosine kinases such as EGFR and ALK, it has been challenging to target KRAS directly due to a high affinity of KRAS protein for guanosine triphosphate (GTP)/guanosine diphosphate (GDP) and the lack of a clear binding pocket [14]. Recently, small molecular inhibitors against KRAS Gly12Cys (G12C) have been developed [15] and showed promises in human clinical trials, including AMG510 [16,17] and MRTX849 [18,19]. These inhibitors selectively modify the mutant cysteine residue in GDP-bound KRAS G12C and inhibit GTP-loading and downstream KRAS-dependent signaling [20]. In phase I clinical trial with AMG510, the therapy is promising with a partial response [21] in two patients and a stable disease in other two patients [16]. Thus, genetic mutations/signaling pathways-based targeted therapies for lung cancer will demonstrate promise of success in the future.

\section{Lung Tumor Initiation}

Tumor-initiating cells (TICs), or cancer stem cells (CSCs), have unique characteristics such as the ability to self-renew, give rise to alternative progeny, initiate and maintain tumors, and activate anti-apoptotic and pro-immortalization pathways [22]. The majority of these characteristics are also seen in stem cells [22]. It is due to this similarity that there are a couple ways implemented to identify TICs such as marker-based strategy by isolating cells with similar cell surface markers seen in normal stem cells as well as marker independent strategy to identify the side populations [23]. The reason underlying the creation of different models and assays to determine TICs is due to their roles in tumor initiation and drug resistance. TICs are able to initiate tumorigenesis by regulating self-renewal genes that can lead to uncontrolled growth. For example, through the sphere formation model, $\mathrm{CD} 44^{+}$cells in NSCLC were found to initiate tumorigenesis by aberrant expression of octamer binding transcription factor 4 (OCT4), SRY-box transcription factor 2 (SOX2), and Nanog homeobox (NANOG), genes known to be regulators of self-renewing and differentiation abilities in cells [24]. Other currently known biomarkers of lung cancer TICs include CD133 ${ }^{+}$[25], CD166 ${ }^{+}$[26], and CD24 ${ }^{+}$ITGB4 $^{+} \mathrm{Notch}^{\text {hi }}$ [27]. Furthermore, signaling pathways that act as either oncogenes or tumor suppressors in lung cancer, such as notch, wingless-related integration site and hedgehog have been found to be abnormally expressed in TICs, indicating TICs expression of these signaling pathways can lead to tumorigenesis in lung cancer [28]. TICs can become drug resistant by going into a quiescent state (side population) that allows them to not be targeted by chemotherapeutic agents that target actively dividing cells [29]. One of the factors that allows side populations to enter a non-dividing stage is epithelial-mesenchymal transition (EMT) [30]. CD44 $4^{+} \mathrm{CD} 90^{+}$side populations in NSCLC and SCLC have been shown to increase 
the expression of the mesenchymal markers N-Cadherin and Vimentin, which led to promotion of EMT and hence drug resistance in these cell lines [24]. CD133 ${ }^{+}$cells in NSCLC have been shown to express high levels of ATP-binding cassette G2 [16], a transporter that can lower intercellular drug concentration through efflux of drugs [24,31]. Other studies have shown $\mathrm{CD} 133^{+}$of being capable of self-renewal, hence implicating $\mathrm{CD} 133^{+}$in drug resistance and the ability to recreate original tumor growth [32]. An overall problem in targeting TICs is that their microenvironment induces changes to the phenotype of TICs. This plasticity means that eradication of TICs may lead to the creation of TICs from dormant ones, and is why Plaks and colleagues advocate the targeting of TICs microenvironment, which includes some of the aforementioned pathways and genes [33].

Overall, the first step in lung tumor initiation is for a cell to become immortalized [34], which occurs by ensuring its telomeric DNA is not shortened through the action of telomerase [35]. Historically, it was believed that the upregulation/activation of the gene telomerase reverse transcriptase (hTERT) solely leads to immortalization [35], but recent research suggests that immortalization is a two-step process in which hTERT promoter mutations and further subsequent upregulation of telomerase occurs [36,37]. For instance, tracheobronchial epithelial cells were shown to not become immortalized by the expression of hTERT alone, exemplifying other factors are involved in lung epithelial cell immortalization [38]. Others suggest that cyclin dependent kinase 4 (CDK4) is also involved in immortalization as co-transfection of CDK4 and hTERT were needed in order for human bronchial epithelial cells to become immortal [34]. After cells become immortalized, genetic mutations of oncogenes and the inactivation of tumor suppressors are the next critical step in lung tumor initiation for both NSCLC and SCLC [39]. The alteration of certain oncogenes and the inactivation of certain tumor suppressor cells tends to be more prevalent depending on the type and subtype of lung cancer. For instance, adenocarcinoma is generally induced in part to alterations in KRAS, ALK, ROS proto-oncogene 1 (ROS1), Ret proto-oncogene (RET), neurotrophic receptor kinase 1 and neuregulin [40]. Furthermore, squamous cell carcinoma is commonly a byproduct of mutations in TP53, cyclin dependent kinase inhibitor $2 A$ (CDKN2A), SOX2, and akt serine/thereonine kinase (AKT) [41]. In SCLC, mutations of $r b$ transcriptional corepressor 1 (RB1) and TP53 [42] are a more common occurrence compared to NSCLC [43]. TP53 is a well-known tumor suppressor, whose alteration leads to uncontrolled cellular growth [44]. Conversely, EGFR is an oncogene that has been widely examined and whose activation, regardless of the pathway/mechanism, is a main culprit in lung tumor initiation, evidenced by its mutation being observable in $43 \%-89 \%$ of cases regarding NSCLC $[45,46]$. Overall, lung tumor initiation involves immortalization followed by transformation mediated by activation of oncogenes and inactivation of tumor suppressors.

\section{Lung Tumor Progression}

Metastasis initiating cells (MICs) are TICs with the ability to initiate a secondary tumor growth site [47]. For example, breast cancer stem cells with the cell markers CD $44^{+}$and CD24-/low have been shown to initiate tumorigenesis after chemotherapy and begin the process of metastasizing to the lung [48]. Yet, Celia-Terrassa et al. contend that if TICs are to be involved in both initiation and metastasis, they must have additional capabilities seen in TICs in order to survive conditions faced when they escape the primary tumor site [49]. For instance, in addition to the self-renewal and plasticity capabilities described before with TICs, researchers theorize that MICs must have mesenchymal-to-epithelial capabilities in order to attach at a secondary metastatic lesion [49]. Brain metastasis initiating cells from the lung increase epithelial development to colonize the brain through the targeting of genes such as forkhead box $\mathrm{C} 2$, noggin and fibroblast growth factor receptor 2 [50]. In addition, Celia-Terrassa and colleagues also contend that MICs must be able to reprogram their metabolism as primary and secondary tumor sites that can have different metabolites available [49]. This idea of reprogramming to combat stress in the cellular environment is a common occurrence in lung cancer metabolism via aerobic glycolysis and oxidative phosphorylation, so with an abundance of glucose present in lung cancer the MICs are able to have enough resources to further progress [51]. 
After a cell becomes immortalized and has become transformed through the activation of oncogenes and inactivation of tumor suppressor genes, research suggest the first step in metastasis begins with tumor cells invading the stroma of its primary tumor site [52]. After successful invasion of the stroma, a tumor cell must form new blood vessels before it spreads to other areas of the body by releasing protein factors that are members of the vascular endothelial growth factor (VEGF) family and binding to VEGF receptors [53]. Although primary tumors promote angiogenesis, they still tend to exceed their blood supply and subsequently hypoxic conditions are induced [54]. Typically, cells will undergo apoptosis under such conditions, but tumor cells are able to upregulate both hypoxia-inducible factor 1 alpha (HIF-1 $\alpha$ ) and hypoxia-inducible factor 2 alpha (HIF-2 $\alpha$ ), which synergistically leads to the transcription of VEGF and hence the creation of more blood vessels [55]. Specific types of cancer cells are also able to activate other pathways in order to survive the hypoxic conditions they create. For instance, upregulated expressions of Notch 1 in hypoxic lung adenocarcinoma cells activate insulin-like growth factor 1 receptor (IGF1R) via binding to the IGF1R promoter directly leading to activation of Akt1, which allows the tumor cells to survive under hypoxic parameters [56]. It is important to note that angiogenesis and hypoxia can lead to EMT, which in addition to affecting TICs (initiation) can also give tumor cells properties of invasion and movement that aid in metastasis [57]. The next step before a tumor cell can migrate and expand in secondary areas is for these cells to evade their hosts' immune response, usually done by tumor cells through the evasion of cytotoxic T lymphocytes (CTLs), antigen presenting cells (APCs) and other components of the innate immune response [52,56]. The ability of a tumor cell to undergo the aforementioned changes allows it to progress to the point where it is ready to migrate to other areas where it can begin to metastasize. Once the tumor cell is ready to leave the blood supply, it exits through a process called extravasation, where it subsequently creates new blood vessels and begins to metastasize at the secondary tumor location [58].

Most of the therapeutic approaches against lung cancer include the targeting of processes that allow tumors to initiate and progress. The main therapies include EGFR tyrosine kinase inhibitors (TKIs) (gefitinib [59,60], afitinib [61], and osimertinib [61]), ALK inhibitors (crizotinib [62], certinib [62], alectinib [62], and lortatinib [63]), and KRAS inhibitors (AMG510 [16], MRTX849 [18] and BI-2852 [64]). Yet, many tumor cells develop resistance. Cells resistant to EGFR TKIs may undergo T790M substitution [65] and C797S mutation [66,67]. A mutation that aids EGFR resistance against all generations of EGFR-TKIs is tyrosine-protein kinase Met (c-MET) gene amplification [68]. Since both of these mutations work hand in hand, previous and recent research suggests co-targeting both EGFR and c-MET in lung cancer [69]. Another common mutation is through the Echinoderm microtubule-associated protein-like 4 (EML4) and ALK mutations [70], but resistance prevailed due to mutations in C1156Y and L1196M within EML4-ALK [70]. KRAS in NSCLC include G12C (most common), G12D, G13D and G12V [71]. Currently resistance against AMG510 is due in part to the fact that G12C inhibitor only binds to the inactive state of G12C. After G12C inhibitor is introduced into a culture they induce lower overall KRAS activity, but after a brief period KRAS activity resumes due to the production of new G12C that is in an active state, making G12C inhibitor obsolete, as they are not able to bind to their targets and inhibit them [72].

In addition to drug resistance via genetic mutations, clinicians also have to deal with drug tolerance. The reason for this concern is due to drug tolerance and drug resistance having a complex synergistic relationship in which drug-tolerant "persisters" lead to drug resistance [73]. Persisters are subpopulations of cancer cells that go into a quiescence state to avoid traditional therapeutics aimed at inhibiting tumor cell growth [74]. Recently, a study focusing on EGFR T790M- drug tolerant cells found them to evolve the EGFR T790 mutation after initial survival to drugs [75]. Due to the interplay between drug tolerant and drug resistant cells, researchers have advocated targeting both of these cells to avoid persisters from also becoming resistant [75]. Researchers have begun to take this approach as after it was found that aurora kinase A, activated by TPX2 microtubule nucleation factor leads to drug tolerance of $3^{\text {rd }}$ generation EGFR TKIs, both EGFR TKIs and aurora kinase A inhibitors were found to induce apoptosis and lower the growth of acquired resistant cells [76]. 


\section{Non-Coding RNA Network in Lung Cancer}

miRNAs are a class of non-coding RNAs whose main function is to regulate gene expression at a post-transcriptional level [77]. miRNAs accomplish the aforementioned purpose by either binding to messenger RNA (mRNA) and disturbing mRNAs translational activity or by initiating mechanisms that promote mRNA decay factor activity that leads to increase mRNA degradation [77]. The ability of miRNAs to repress mRNA that has led to its identification as a major player in lung tumor initiation and progression [78]. Another non-coding RNA that has a key role in lung tumorigenesis and metastasis is long non-coding RNA (lncRNA). Unlike miRNAs, lncRNAs manifest themselves in lung cancer by regulating gene expression not only at the post-transcriptional level, but also at the transcriptional and epigenetic level [79]. It is important to note that lncRNAs and miRNAs are able to interact with each other, evidenced by the ability of lncRNAs to act as miRNA sponges, where IncRNAs can increase or decrease miRNAs effect on mRNA by outcompeting substrates that traditionally bind to miRNAs [80]. Circular RNA (circRNA) forms a covalently closed continuous loop and function as a sponge for a particular miRNA or RNA binding protein [81]. The roles of circRNAs in lung tumor as biomarkers and master regulators have been reviewed [82]. Several interactions between lncRNAs, circRNAs, and miRNAs will be discussed below along with non-coding RNAs effect, mediated by their upregulation or downregulation, on downstream targets implicated to have a role in lung tumor initiation and progression [80].

\subsection{Role of Non-Coding RNAs in Lung Tumor Initiation}

\subsubsection{Role of Non-Coding RNAs in Lung Tumor Initiating Cells}

Dysregulation of certain non-coding RNAs in lung TICs control tumor initiation and progression. For instance, upregulation of miR-1246 and miR-1290 led to repression of metallothioneins, especially metallothionein 1G (MT1G), which led to increased TIC ability to initiate tumor growth and metastasis in NSCLC (Table 1) [83]. Metallothioneins play key roles in tumor growth as they regulate zinc levels required for G1/S phase transition and increase expression of matrix metalloproteinase 3 [84]. Upregulation of miR-494-3p led to activation of Notch 1 and PI3K signaling pathways, which increased TICs ability to proliferate [85]. On the other hand, miR-145 inhibits TIC proliferation by directly targeting and repressing OCT4 mRNA [86]. Decreased levels of miR-31 and elevated levels of let-7 cooperatively inhibited growth of lung TICs through the cell cycle arrest [87]. Alternatively, signal transducer and activator of transcription 3 (STAT3) activation-induced upregulation of the lncRNA HOX transcript antisense RNA (HOTAIR) via its promoter activity promoted lung tumorigenesis through EMT (Table 2) [88]. Knocking down HOTAIR inhibits features of TICs including frequencies of side population cells and spheroid forming cells [88]. Chen and colleagues recently reviewed regulations of lncRNAs in TICs in several types of cancers [89]. Thus, it is imperative to find whether these lncRNAs are able to affect TICs involved in lung tumorigenesis to find avenues of targeting these lncRNAs. 
Table 1. miRNAs involved in lung cancer initiation and progression.

\begin{tabular}{|c|c|c|c|c|c|}
\hline miRNA & $\begin{array}{l}\text { Lung Cancer } \\
\text { Subtype }\end{array}$ & $\begin{array}{l}\text { Downstream } \\
\text { Direct Targets }\end{array}$ & Hallmark & $\begin{array}{c}\text { Initiation } \\
\text { (I)/Progression (P) }\end{array}$ & References \\
\hline \multicolumn{6}{|c|}{ Upregulated miRNAs } \\
\hline miR-21 & NSCLC & PDCD4, APAF1 & Inactivation of Tumor Suppressor & I & [90] \\
\hline miR-31 & NSCLC & $\begin{array}{l}\text { RASA1, SPRED1/2, } \\
\text { SPRY1/3/4 }\end{array}$ & Inactivation of Tumor Suppressor & I & [91] \\
\hline miR-196a & NSCLC & HOXA5 & Promotion of Metastasis & $\mathrm{P}$ & [93] \\
\hline miR-18a-5p & NSCLC & IRF2 & $\begin{array}{l}\text { Promotion of Proliferation and } \\
\text { Inhibition of Apoptosis }\end{array}$ & I & [94] \\
\hline $\begin{array}{l}\text { miR-25, miR-93, } \\
\text { miR-106b }\end{array}$ & NSCLC & $\mathrm{p} 21$ & Promotion of Proliferation & $\mathrm{P}$ & [95] \\
\hline miR-574-5p & SCLC & PTPRU & Promotion of Metastasis & $\mathrm{P}$ & [98] \\
\hline $\operatorname{miR}-494$ & NSCLC & PTEN & Promotion of Angiogenesis & $\mathrm{P}$ & [99] \\
\hline $\mathrm{miR}-221 / 222$ & NSCLC & APAF1 & $\begin{array}{l}\text { Promotion of Drug Resistance to } \\
\text { EGFR TKI gefitinib }\end{array}$ & $\mathrm{P}$ & [100] \\
\hline $\mathrm{miR}-30 \mathrm{~b} / \mathrm{c}$ & NSCLC & BIM & $\begin{array}{l}\text { Promotion of Drug Resistance to } \\
\text { EGFR TKI gefitinib }\end{array}$ & $\mathrm{P}$ & [100] \\
\hline miR-21 & NSCLC & PTEN & $\begin{array}{l}\text { Promotion of Drug Resistance to } \\
\text { EGFR TKI gefitinib }\end{array}$ & $\mathrm{P}$ & [101] \\
\hline miR-147b & LUAD & VHL, SDH & $\begin{array}{c}\text { Promotion of Drug Tolerance to } \\
\text { EGFR TKI osimertinib }\end{array}$ & $\mathrm{P}$ & [102] \\
\hline \multicolumn{6}{|c|}{ Downregulated miRNAs } \\
\hline let-7 & NSCLC & RAS & Activation of Oncogene & $\mathrm{I}$ & [104] \\
\hline miR-33 & NSCLC & METTL3 & Promotion of RNA Modifications & $\mathrm{I}$ and $\mathrm{P}$ & {$[105]$} \\
\hline miR-193a-5p & NSCLC & PIK3R3, mTOR & Promotion of Metastasis & $\mathrm{P}$ & [106] \\
\hline miR-193a-3p & NSCLC & ERBB4, S6K2 & Promotion of Metastasis & $\mathrm{P}$ & [106] \\
\hline miR-335 & SCLC & RANKL & Promotion of Metastasis & $\mathrm{P}$ & [107] \\
\hline miR-126 & LUAD & VEGFA & Promotion of Angiogenesis & $\mathrm{P}$ & [108] \\
\hline miR-195 & LUSC & VEGFA & Promotion of Angiogenesis & $\mathrm{P}$ & [109] \\
\hline $\mathrm{miR}-34 \mathrm{a} / \mathrm{b} / \mathrm{c}$ & NSCLC & PDL1 & $\begin{array}{l}\text { Evasion of Host Immune } \\
\text { Response }\end{array}$ & $\mathrm{P}$ & [110] \\
\hline $\operatorname{miR}-140$ & NSCLC & PDL1, CCNE1 & $\begin{array}{c}\text { Evasion of Host Immune } \\
\text { Response }\end{array}$ & $P$ & {$[111]$} \\
\hline
\end{tabular}

Abbreviations: Apoptosis peptidase activating factor 1 (APAF1), BCL-2-like protein 11 (BIM), cyclin E1 (CCNE1), endoribonuclease dicer (DICER), endothelial PAS domain protein 1 (EPAS1), Erb-B2 receptor tyrosine kinase 4 (ERBB4), hypoxia-inducible factor $1 \propto(\mathrm{HIF}-1 \alpha)$, homeobox A5 (HOX5A), interferon regulatory factor 2 (IRF2), forkhead box O3 (FOXO3), lung adenocarcinoma (LUAD), lung squamous cell carcinoma (LUSC), methyltransferase like 3 (METTL3), mechanistic target of rapamycin kinase (mTOR), metallothionein 1G (MT1G), MYC proto-oncogene (MYC), non-small cell lung carcinoma (NSCLC), phosphatase and tensin homolog (PTEN), programmed cell death 4 (PDCD4), phosphoinositide-3-kinase regulatory subunit 3 (PIK3R3), protein kinase C epsilon (PKC- $\varepsilon$ ), programmed cell death 1 ligand 1 (PDL1/CD274), protein tyrosine phosphatase receptor type U (PTPRU), tumor necrosis factor ligand superfamily member 11 (RANKL), RAS p21 protein activator 1 (RASA1), RB transcriptional corepressor like 2 (RBL2), sprouty related EVH1 domain containing 1 (SPRED1), sprouty 1 (SPRY1), SRC proto-oncogene non-receptor tyrosine kinase (SRC), TIMP metallopeptidase inhibitor (TIMP2), small cell-lung cancer (SCLC), vascular endothelial growth factor A (VEGFA), ribosomal protein S6 kinase B2 (S6K2), von Hipper-Lindau tumor suppressor (VHL). 
Table 2. Long non-coding RNAs and circular RNAs involved in lung cancer initiation and progression.

\begin{tabular}{|c|c|c|c|c|c|}
\hline $\begin{array}{l}\text { LncRNA and } \\
\text { circRNA }\end{array}$ & $\begin{array}{l}\text { Lung Cancer } \\
\text { Subtype }\end{array}$ & $\begin{array}{l}\text { Downstream } \\
\text { Direct Targets }\end{array}$ & Hallmark & $\begin{array}{c}\text { Initiation } \\
\text { (I)/Progression (P) }\end{array}$ & References \\
\hline \multicolumn{6}{|c|}{ Upregulated LncRNAs } \\
\hline HOTAIR & NSCLC & N.A. & Enrichment of TICs & I & [88] \\
\hline SBF2-AS1 & NSCLC/SCLC & SUZ12, EZH2 & $\begin{array}{c}\text { Promotion of Tumor Cell } \\
\text { Proliferation }\end{array}$ & $\mathrm{P}$ & [112] \\
\hline LINC00312 & LUAD & YBX1 & $\begin{array}{l}\text { Promotion of Vasculogenic } \\
\text { Mimicry and Metastasis }\end{array}$ & $\mathrm{P}$ & [113] \\
\hline MEG3 & NSCLC & JARID2 & Promotion of TGF $\beta$-induced EMT & I and $P$ & [114] \\
\hline HOXA-AS3 & LUAD, LUSC & HOXA3 & $\begin{array}{l}\text { Promotion of Drug Resistance to } \\
\text { Platinum-based Chemotherapy }\end{array}$ & $\mathrm{P}$ & [115] \\
\hline SOX2OT & LUSC & N.A. & $\begin{array}{c}\text { Promotion of Tumor Cell } \\
\text { Proliferation }\end{array}$ & $\mathrm{P}$ & [116] \\
\hline H19 & NSCLC & miR-107 & $\begin{array}{c}\text { Promotion of Tumor Cell } \\
\text { Proliferation }\end{array}$ & $\mathrm{P}$ & [117] \\
\hline ANRIL & NSCLC & EZH2 & $\begin{array}{l}\text { Promotion of Tumor Cell } \\
\text { Proliferation and Metastasis }\end{array}$ & $\mathrm{P}$ & [118] \\
\hline CAR10 & LUAD & $\begin{array}{l}\operatorname{miR}-30, \\
\operatorname{miR}-203\end{array}$ & Promotion of Metastasis & $\mathrm{P}$ & [119] \\
\hline MALAT1 & NSCLC & miR-204 & Promotion of Metastasis & $\mathrm{P}$ & [120] \\
\hline PVT1 & NSCLC & miR-195 & $\begin{array}{c}\text { Promotion of Resistance to } \\
\text { Radiotherapy }\end{array}$ & $\mathrm{P}$ & [121] \\
\hline ВС087858 & NSCLC & N.A. & $\begin{array}{c}\text { Promotion of Drug Resistance to } \\
\text { EGFR TKI gefitinib }\end{array}$ & $\mathrm{P}$ & [122] \\
\hline \multicolumn{6}{|c|}{ Downregulated LncRNAs } \\
\hline LINC01186 & NSCLC & N.A. & Inhibition of TGF $\beta$-induced EMT & $\mathrm{P}$ & {$[123,124]$} \\
\hline LincRNA-p21 & LUAD & N.A. & $\begin{array}{c}\text { Promotion of Hypoxia-induced } \\
\text { Angiogenesis }\end{array}$ & $\mathrm{P}$ & [125] \\
\hline HOTAIRM1 & LUAD & HOXA1 & $\begin{array}{l}\text { Inhibition of Evasion of Hosts } \\
\text { Immune Response }\end{array}$ & $\mathrm{P}$ & [126] \\
\hline PANDAR & NSCLC & NF-YA & $\begin{array}{c}\text { Inhibition of Tumor Cell } \\
\text { Proliferation }\end{array}$ & $\mathrm{P}$ & [127] \\
\hline MIR22HG & NSCLC & YBX1 & $\begin{array}{l}\text { Inhibition of Tumor Cell } \\
\text { Proliferation }\end{array}$ & $\mathrm{P}$ & [128] \\
\hline GAS5 & NSCLC & N.A. & $\begin{array}{c}\text { Inhibition of Tumor Cell } \\
\text { Proliferation, Activation of Tumor } \\
\text { Suppressors }\end{array}$ & $\mathrm{I} / \mathrm{P}$ & [129] \\
\hline GAS5 & NSCLC & IGF-1R & $\begin{array}{c}\text { Promotion of Apoptosis, } \\
\text { Inhibition of Drug Resistance to } \\
\text { EGFR TKI gefitinib }\end{array}$ & $\mathrm{P}$ & [130] \\
\hline \multicolumn{6}{|c|}{ Upregulated circRNAs } \\
\hline circFGFR1 & NSCLC & $\operatorname{miR}-381-3 p$ & $\begin{array}{l}\text { Promotion of Progression and } \\
\text { Resistance to Immune Checkpoint } \\
\text { Inhibitors }\end{array}$ & $P$ & {$[131,132]$} \\
\hline circ_0020123 & NSCLC & miR-144 & $\begin{array}{l}\text { Promotion of Tumor Cell } \\
\text { Proliferation }\end{array}$ & $\mathrm{P}$ & [133] \\
\hline circTP63 & LUSC & miR-873-3p & $\begin{array}{l}\text { Promotion of Tumor Cell } \\
\text { Proliferation }\end{array}$ & $\mathrm{P}$ & [134] \\
\hline $\operatorname{circPRKCI}$ & LUAD & $\begin{array}{l}\text { miR-545, } \\
\text { miR-589 }\end{array}$ & $\begin{array}{l}\text { Promotion of Tumor Cell } \\
\text { Proliferation, Promotion of Drug } \\
\text { Resistance to EGFR TKI gefitinib }\end{array}$ & $\mathrm{P}$ & [135] \\
\hline circ_0000064 & NSCLC & N.A. & $\begin{array}{l}\text { Promotion of Tumor Cell } \\
\text { Proliferation and Metastasis, } \\
\text { Inhibition of Cell Apoptosis }\end{array}$ & $\mathrm{P}$ & [136] \\
\hline F-circEA & NSCLC & N.A. & Promotion of Metastasis & $\mathrm{P}$ & [137] \\
\hline circ_0067934 & NSCLC & N.A. & Promotion of EMT and Metastasis & $\mathrm{P}$ & {$[138]$} \\
\hline CDR1as & NSCLC & miR-7 & $\begin{array}{l}\text { Activation of Oncogene, } \\
\text { Inhibition of Apoptosis }\end{array}$ & $\mathrm{P}$ & [139] \\
\hline circ_103809 & NSCLC & miR-4302 & Activation of Oncogene & $\mathrm{P}$ & [140] \\
\hline
\end{tabular}


Table 2. Cont.

\begin{tabular}{|c|c|c|c|c|c|}
\hline $\begin{array}{l}\text { LncRNA and } \\
\text { circRNA }\end{array}$ & $\begin{array}{l}\text { Lung Cancer } \\
\text { Subtype }\end{array}$ & $\begin{array}{l}\text { Downstream } \\
\text { Direct Targets }\end{array}$ & Hallmark & $\begin{array}{c}\text { Initiation } \\
\text { (I)/Progression (P) }\end{array}$ & References \\
\hline \multicolumn{6}{|c|}{ Downregulated circRNAs } \\
\hline cir-ITCH & NSCLC & miR-7, miR-214 & $\begin{array}{l}\text { Inhibition of Tumor Cell } \\
\text { Proliferation }\end{array}$ & $\mathrm{P}$ & [141] \\
\hline circ_100395 & NSCLC & miR-1228 & $\begin{array}{c}\text { Inhibition of Tumor Cell } \\
\text { Proliferation and Metastasis }\end{array}$ & $\mathrm{P}$ & [142] \\
\hline circ_0033155 & NSCLC & PTEN & $\begin{array}{l}\text { Inhibition of Tumor Cell } \\
\text { Proliferation and Metastasis }\end{array}$ & $\mathrm{P}$ & [143] \\
\hline circRNF13 & NSCLC & miR-93-5p & Inhibition of Metastasis & $\mathrm{P}$ & [144] \\
\hline
\end{tabular}

Abbreviations: antisense non-coding RNA in the INK4 locus (ANRIL), BCL-2-like protein 4 (BAX), chromatin-associated RNA 10 (CAR10), enhance of zeste 2 polycomb repressive complex 2 subunit (EZH2), growth arrest-specific transcript 5 (GAS5), homeobox A1 (HOXA1), HOX transcript antisense RNA (HOTAIR), HOXA transcript antisense RNA, myeloid-specific 1 (HOTAIRM1), HOXA cluster antisense RNA 3 (HOXA-AS3), insulin like growth factor receptor 1 (IGF-1R), homeobox A3 (HOXA3), Jumonji and at-rich interaction domain containing 2 (JARID2), lung squamous cell carcinoma (LUSC), lung adenocarcinoma (LUAD), metastasis-associated lung adenocarcinoma transcript 1 (MALAT1), maternally expressed 3 (MEG3), nuclear transcription factor Y, alpha (NF-YA), non-small cell lung carcinoma (NSCLC), promoter of CDKN1 antisense DNA damage-activated RNA (PANDAR), phosphatase and tensin homolog (PTEN), plasmacytoma variant translocation 1 (PVT1), small cell lung carcinoma (SCLC), SOX2 overlapping transcript (SOX2OT), SUZ12 polycomb repressive complex 2 subunit (SUZ12), Y-Box binding protein 1 (YBX1), not available, (N.A.).

\subsubsection{Role of Non-Coding RNAs in Immortalized Genes}

Recent evidence has shown that non-coding RNAs mediate oncoprotein-induced immortalization of lung epithelial cells. Activation of Simian virus 40 small T antigen (SV40 ST) and TERT in human bronchial epithelial cells induces an upregulation of miR-27a leading to enhanced immortalization. miR-27a mediated immortalization is through repressing downstream cell cycle regulator F-box/WD repeat-containing protein 7 (FBXW7) (Table 1) [145]. On the other way, miRNAs are involved in the immortalization process through promoting expressions of immortalized gene hTERT or CDK4 directly in lung cancer. For example, downregulated miR-545 expression in NSCLC enhances expressions of CDK4 leading to enhanced cell proliferation [146]. Similarly, other tumor suppressive miRNAs including miR-486-5p [147], miR-613 [148], miR-340 [149], and miR-34b-3p [150] upregulate expression of CDK4 in NSCLC. Although few studies of non-coding RNAs involved in the immortalization process have been demonstrated in lung cancer, the aforementioned data suggests that these links could provide valuable therapeutic targets.

\subsubsection{Role of Non-Coding RNAs in Oncogenes and Tumor Suppressors}

The ability of non-coding RNAs to interact with oncogenes is a valuable hallmark in lung tumor initiation and progression. The first miRNA discovered was let-7 family including let-7a, let-7b, let-7c, let-7d, let-7e, let-7f, let-7g, let-7i, miR-98, and miR-202 [151]. let-7 family members bind to the $3^{\prime}$ untranslated regions ( $3^{\prime}$ UTR) of RAS oncogene and is downregulated in lung cancers (Table 1) [104].

Tumor suppressor control non-coding RNA expressions, and vice versa. Tumor suppressor p53 directly regulates cancer suppressive $\mathrm{miR}-34 \mathrm{a} / \mathrm{b} / \mathrm{c}$ expression via manipulating promoter activity of miR-34 in lung cancer [152]. Reduced miR-34 expression promotes lung tumor initiation via derepressing cell-cycle regulatory genes including Met and Bcl-2 [153]. On the other way, upregulation of miR-21 in NSCLC enhances KRAS-driven tumor initiation via repressing tumor suppressors including programmed cell death 4 (PDCD4) and apoptosis peptidase activating factor 1 (APAF1) [90]. Similarly, overexpression of miR-31 increases tumorigenesis via decreasing RAS p21 protein activator 1 (RASA1), sprouty related EVH1 domain containing 1/2 (SPRED1/2), and Sprouty 1/3/4 (SPRY1/3/4) in KRAS-driven NSCLC [91]. In SCLC, overexpression of the miR-17 92 cluster including seven miRNAs promotes the tumor development through repressing tumor suppressor PTEN and RB transcriptional corepressor like 2 (RBL2) [92]. 
Another key relationship between non-coding RNAs and lung cancer is how miRNAs can be used as diagnostic markers. The upregulation of both miR-205 and miR-375 has successfully distinguish lung squamous cell carcinoma from lung adenocarcinoma [154]. Further research on miRNAs and lncRNAs as biomarkers in histological subtyping is advocated as more patient-specific treatments can be provided once the tumor type is known.

\subsubsection{Role of Non-Coding RNAs in RNA Editing}

RNA editing is the process of an RNA editor changing nucleotide sequences in RNA to change the way a codon is read by ribosomes [155]. In addition to regulating mRNA, RNA editors can also affect non-coding RNAs such as miRNAs and lncRNAs expression, and hence play a role in cancer initiation and progression [156]. The commonly known RNA editing event is adenosine to inosine (A-to-I) conversion catalyzed by adenosine deaminase acting on RNA (ADAR) (Figure 1) [157]. Previous studies have demonstrated that ADAR1 inhibits miRNA processing globally through forming ADAR1/Dicer complex via the RNA interference machinery [158]. Although most ADAR editing occurs in non-coding regions in lung cancer, few studies have shown the crosstalk between ADAR and non-coding RNAs [159]. Anadon et al. have demonstrated that ADAR1 gene amplification in NSCLC promotes tumor growth via enhanced A-to-I editing of RNA transcripts including miR-381 [160]. It is consistent to previous finding that reduced miR-381 expression promotes tumor cells proliferation and resistance to platinum-based chemotherapy via upregulating inhibitor of DNA binding 1 (ID1) levels directly in NSCLC [161]. Furthermore, Nigita et al. have shown dysregulated miRNA editing events in both tumor tissues and circulating exosomes in NSCLC, such as miR-411-5p [162]. As for ADAR editing on lncRNAs, a database of "LNCediting" has been developed to identify lncRNAs that undergo ADAR editing [163]. LNCediting could potentially predict roles of interactions of ADAR and lncRNAs in lung tumor initiation and progression. A role in RNA editing of non-coding RNAs has been established and found to have wide-ranging effects on prognosis. An avenue in which regulation of RNA editing to hence modify non-coding RNAs should be explored to inhibit negative effects of RNA editing and increase patient prognosis.

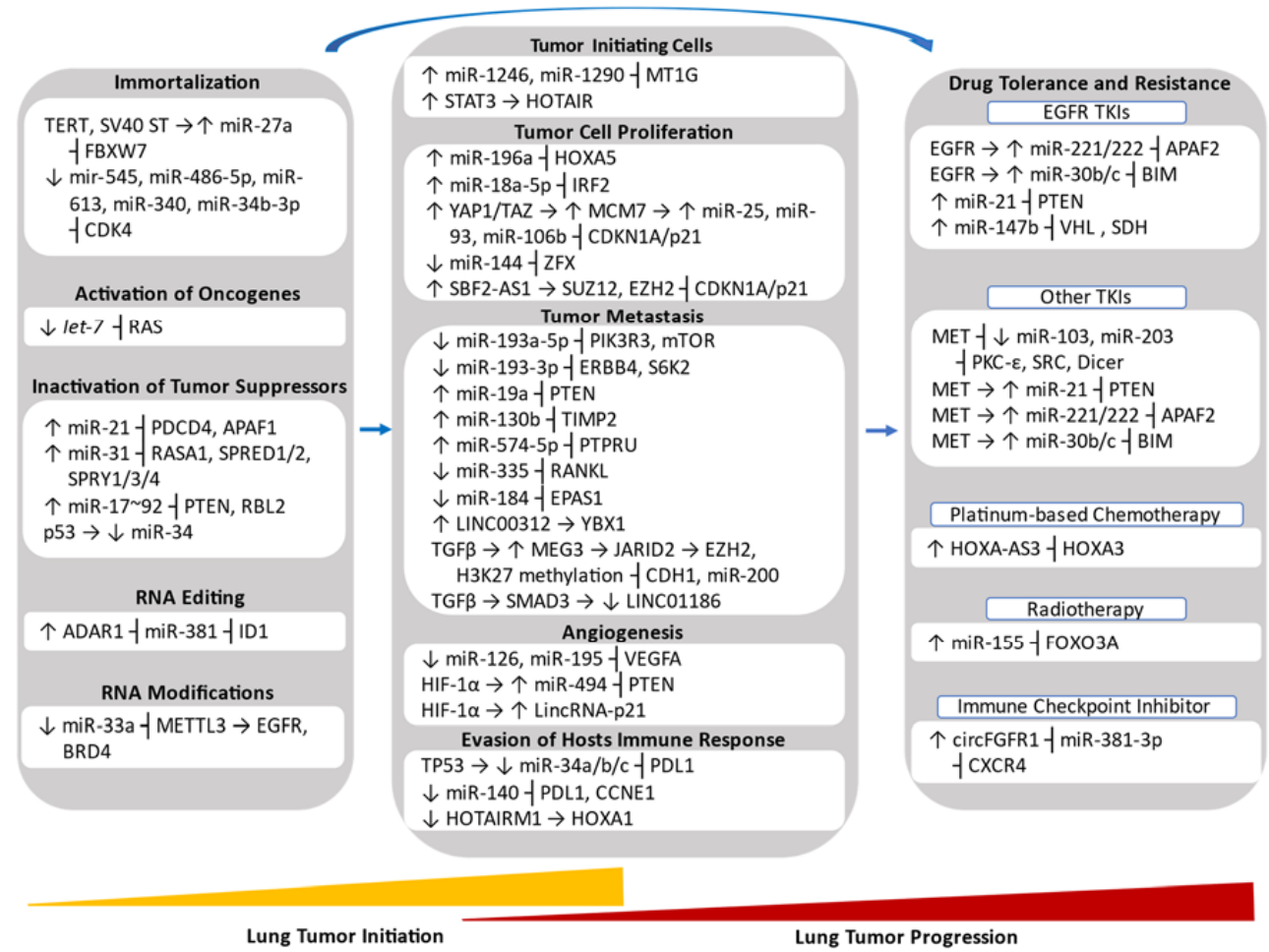

Figure 1. Non-coding RNAs involved in lung cancer initiation and progression along with the hallmark 
they affect. $\uparrow$, upregulation; $\downarrow$, downregulation; $\rightarrow$, promotion; $\dashv$, inhibition. Abbreviations: Apoptotic peptidase activating factor 1/2 (APAF1/2), BCL-2-like protein 11 (BIM), bromodomain-containing protein 4 (BRD4), cyclin E1 (CCNE1), E-cadherin (CDH1), cyclin dependent kinase 4 (CDK4), cyclin dependent kinase inhibitor 1A (CDKN1A), C-X-C motif chemokine receptor 4 (CXCR4), endoribonuclease Dicer (DICER), epidermal growth factor receptor (EGFR), endothelial PAS domain protein 1 (EPAS1), Erb-B2 receptor tyrosine kinase 4 (ERBB4), enhance of zeste 2 polycomb repressive complex 2 subunit (EZH2), F-box and WD repeat domain containing 7 (FBXW7), forkhead box O3 (FOXO3A), hypoxia inducible factor 1 alpha (HIF-1 $\alpha$ ), homeobox A3 (HOXA3), homeobox A5 (HOXA5), inhibitor of DNA binding 1 (ID1), interferon regulatory factor 2 (IRF2), Jumonji and AT-rich interaction (JARID2), minichromosome maintenance complex component 7 (MCM7), methyltransferase like 3 (METTL3), SMAD Family Member 3 (SMAD3), mechanistic target of rapamycin kinase (mTOR), metallothionein 1G (MT1G), protein tyrosine phosphatase receptor type U (PTPRU), programmed cell death 1 ligand 1 (PD-L1), programmed cell death 4 (PDCD4), phosphatidylinositol-3-kinase regulatory subunit 3 (PIK3R3), phosphatase and tensin homolog (PTEN), protein kinase $C$ epsilon (PKC- $\varepsilon$ ), tumor necrosis factor ligand superfamily member 11 (RANKL), Ras p21 protein activator (RASA1), retinoblastoma-like protein 2 (RBL2), succinate dehydrogenase (SDH), sprouty related EVH1 domain containing 1/2 (SPRED1/2), sprouty 1 (SPRY1/3/4), SRC proto-oncogene non-receptor tyrosine kinase (SRC), signal transducer and activator of transcription 3 (STAT3), SUZ12 polycomb repressive complex 2 subunit (SUZ12), Simian virus 40 small T antigen (SV40 ST), transforming growth factor beta 1 (TGF $\beta$ ), tissue inhibitor of metalloproteinases 2 (TIMP2), tumor protein 21 (TP21), tumor protein 53 (TP53), telomerase reverse transcriptase (TERT), vascular endothelial growth factor A (VEGFA), von Hipper-Lindau tumor suppressor (VHL), yes associated protein 1/tafazzin (YAP1/TAZ), Y-Box binding protein 1 (YBX1), zinc finger protein X-linked (ZFX).

\subsubsection{Role of Non-Coding RNAs in RNA Modifications}

RNA modifications, including modification of the $5^{\prime}$ cap and $3^{\prime}$ end of mRNA along with their biological significance have been well studied [164]. Recently, $\mathrm{N}^{6}$-methyladenine $\left(\mathrm{m}^{6} \mathrm{~A}\right)$ modifications affecting internal modification of mRNAs have been gaining more attention due to their ability to affect cancer [164]. For example, $\mathrm{m}^{6} \mathrm{~A}$ inducers such as methyltransferase-like 3 (METTL3) have been shown to act as an oncogene by increasing the translation of EGFR in NSCLC (Figure 1) [165]. It has been identified that $\mathrm{m}^{6} \mathrm{~A}$ modifications regulate miRNA biogenesis, and vice versa. For instance, primary microRNAs (pri-miRNAs) are processed into miRNAs by both DiGeorge syndrome critical region gene 8 microprocessor complex subunit (DGCR8) and drosha ribonuclease type II (DROSHA) [166]. METTL3 increases methylation in pri-miRNAs allowing for DGCR8 to bind to and promotes pri-miRNAs processing [166]. Non-coding RNAs also regulate these $\mathrm{m}^{6} \mathrm{~A}$ modifications in lung cancer. Downregulated miR-33a binds to the $3^{\prime}$ UTR of METTL3 and increases METTL3 expression levels [105]. The decrease in levels of METTL3 induced apoptosis and slowed tumorigenesis in NSCLC [105] due that METTL3 promotes translation of oncogenic mRNAs including EGFR [165] and bromodomain-containing protein 4 (BRD4) [167] (Figure 1). It is of consequence to also note that $\mathrm{m}^{6} \mathrm{~A}$ can affect ADAR editing by $\mathrm{m}^{6} \mathrm{~A}$ suppression, which has been correlated to induce increased ADAR editing, this insight is noteworthy as it can be correlated that $\mathrm{m}^{6} \mathrm{~A}$ downregulation can lead to the aforementioned effects of ADAR editing on cancers [168]. With a better understanding of the interactions between RNA modification and their effect on non-coding RNAs, they could serve as potential targets to inhibit lung tumor initiation and progression.

\subsection{Role of Non-Coding RNAs in Lung Tumor Progression}

\subsubsection{Role of Non-Coding RNAs in Tumor Cell Proliferation}

miR-196a was shown to act as an oncogenic miRNA as its upregulation in NSCLC led to inhibition of homeobox A5, which led to proliferation of NSCLC cells (Figure 1; Table 1) [93]. Upregulated miR-18a expression decreases interferon regulatory factor 2 (IRF2) activity leading to decreased cell 
apoptosis and enhanced cell proliferation in NSCLC tumor cells [94]. Upregulated expression of lncRNA SBF2-AS1 promotes NSCLC cell proliferation via direct binding to SUZ12 polycomb repressive complex 2 subunit (SUZ12) and enhancer of zeste 2 polycomb repressive complex 2 subunit (EZH2) using an RNA immunoprecipitation approach (Figure 1; Table 2) [112]. The enrichment of both SUZ12 and EZH2 reduces protein levels of cyclin dependent kinase inhibitor 1A (CDKN1A)/p21 linking DNA damage to cell cycle arrest [169]. Similarly, upregulation of MCM7 gene and its hosted miR-25, miR-93, and miR-106b cluster via binding to minichromosome maintenance complex component 7 (MCM7) promoter by activated yes associated protein 1/tafazzin (YAP1/TAZ) led to increased NSCLC tumor cell proliferation through inhibiting p21 directly [95]. In addition, reduced expression of miR-144 in NSCLC promote tumor cells proliferation and inhibits apoptosis via upregulating zinc finger X-chromosomal protein (ZFX) [170] (Figure 1). It suggests that non-coding RNAs play important roles in lung tumor cell proliferation.

\subsubsection{Role of Non-Coding RNA in Tumor Metastasis}

Pertaining to metastasis, research shows that suppression of the tumor suppressor gene, epithelial cadherin (CDH1), is a key factor in EMT as it allows for the tumor cell to detach from its primary tumor site and metastasize in a secondary site [171]. As illustrated before, MICs have the ability to undergo mesenchymal-epithelial transition to colonize a secondary site and can subsequently target mechanisms to proliferate [50]. One of these mechanisms includes increased expression of signal transducers and activators of transcription 3, which can bind to and increase miR-21 levels, which in turn allows MICs to proliferate and metastasize [172]. In NSCLC, decreased miR-193a-5p and miR-193a-3p expressions linked to enhanced tumor metastasis through upregulating PIK3R3 and mTOR as well as ERBB4 and S6K2, respectively (Figure 1; Table 1) [106]. Alternatively, upregulated miR-19a expression in NSCLC promotes tumor cell metastasis via repressing PTEN [96]. Further study showed that PTEN inactivation led to nuclear translocation of $\beta$-catenin and Snail/Slug in lung cancer cells [173]. The following miRNAs have been found to have a role in tumor cells ability to proliferate/invade/migrate, but the exact hallmark and mechanism is not yet known. miR-130b also acts as an oncogenic miRNA as its upregulation leads to the decreased expression of tissue inhibitor of metalloproteinase-2 (TIMP-2), which leads to increased activity in matrix metallopeptidase 2 and enhanced tumor metastasis [97]. As for SCLC, miR-355 downregulation directly induces increased expression of tumor necrosis factor ligand superfamily member 11 (RANKL) leading to bone metastasis [107]. miR-574-5p is an oncogenic miRNA in SCLC as its promotion leads to repression of protein tyrosine phosphatase receptor type $\mathrm{U}$ (PTPRU), which in turn increases tyrosine phosphorylation of $\beta$-catenin [98]. In contrast, miR-184 has demonstrated downregulation in SCLC and acts as a tumor suppressive miRNA as it represses endothelial PAS domain protein 1 (EPAS1)/HIF-2 $\alpha$ leading to $\beta$-catenin activation [98]. Activation of $\beta$-catenin further regulate E-cadherin pathway linking to tumor cell metastasis [174]. In addition, highly invasive tumor cells promote metastasis by forming fluid-conducting channels, termed as vasculogenic mimicry. For instance, upregulated LINC00312 expression in lung adenocarcinoma tissue induces tumor metastasis and vasculogenic mimicry through direct binding to Y-Box binding protein 1 (YBX1) (Figure 1; Table 2) [113]. Elevated JARID2 recruits EZH2 and induces H3K27 methylation, which repress CDH1 and miR-200 family [114]. In contrast, TGF $\beta$-induced SMAD family member 3 (SMAD3) activation repress expression of lncRNA LINC01186 in NSCLC cells leading to EMT and metastasis [123]. As shown, EMT, tumor cell proliferation, and invasion are key hallmarks involved in lung cancer metastasis that can be promoted by non-coding RNAs. Further research is advocated to block non-coding RNAs ability to spread cancers towards secondary sites through these specific hallmarks [175].

\subsubsection{Role of Non-Coding RNA in Angiogenesis}

As previously mentioned, VEGF has a critical role in angiogenesis. miR-126 and miR-195 are both downregulated in NSCLC which lead to angiogenesis as both miR-126 [108] and miR-195 [109] 
can bind to the $3^{\prime}$ UTR of VEGFA and inhibit its overexpression (Figure 1; Table 1). Tumor cells have the ability to promote angiogenesis during hypoxic conditions. Mao et al. reported that in NSCLC hypoxic conditions induce upregulation of miR-494 in tumor cells that transmit miR-494 into vascular endothelial cells via a microvesicle-mediated route. Repression of PTEN in endothelial cells by miR-494 led to increased phosphorylation of AKT serine/threonine kinase and hence activated the AKT serine/threonine kinase/endothelial nitric oxide synthase pathway that led to an increase in pro-angiogenic factors such as VEGF [99]. IncRNAs are also able to upregulate VEGF expression levels. In lung adenocarcinoma, HIF-1 $\alpha$ activation-induced lincRNA-p21 upregulation promotes angiogenesis through increased production of VEGFA, matrix metallopeptidase 2, and fibroblast growth factor (Figure 1; Table 2) [125]. This insight is related to a previously examined theme that angiogenesis is related to other hallmarks of lung cancer such as hypoxia and EMT, and this suggests that there is high duality of non-coding RNAs that can target different hallmarks in order to advance or suppress oncogenic activity.

\subsubsection{Role of Non-Coding RNA in Evasion of Host Immune System}

Immune checkpoints, or regulatory signals, are important for the regulation of T-cell response. The most extensively studied for targeted immunotherapy in lung cancer include inhibitory receptors cytotoxic T-lymphocyte-associate protein 4 (CTLA4), programmed death protein 1 (PD1), and programmed death ligand 1 (PD-L1) [176]. Additionally, clinical trials have focused on both monotherapy and combination therapy, however poor clinical response to treatment due to acquired resistance have been noted $[177,178]$. Of these receptors, the interaction between PD-L1 and miRNAs have shown the greatest cause for resistance. p53, via miR-34, which can bind to $3^{\prime}$ UTR of PD-L1, is able to repress PD-L1 [110]. p53 can also regulate miR-200/ZEB1 signaling [179]. Chen et al. found that miR-200/ZEB1 axis regulates PD-L1 expression and has a strong correlation with EMT tumors [180]. Another miRNA that binds and inhibits PD-L1 is miR-140 [111]. miR-140 is downregulated in NSCLC, leading to increased expression of PD-L1, which can increase the expression of cyclin E [111], a gene that dysregulates G1-S transition and the S phase in lung tumors to increase their proliferation [181]. Other reported PD-L1 regulators include miR-197 through the miR-197/CKS1B/STAT3 signaling pathway [182] and an inverse relationship with miR-33a [183]. As for lncRNAs, downregulated HOXA transcript antisense RNA, myeloid-specific 1 (HOTAIRM1) in myeloid-derived suppressor cells (MDSCs) in lung adenocarcinoma decreases the level of homeobox 1 leading to loss of immunosuppressive ability for MDSCs (Figure 1; Table 2) [153]. Altogether, these findings suggest that targeting of specific tumor initiating/suppressive genes by varying non-coding RNAs could have an effect on these immune checkpoints by mimicking the role of immune checkpoint inhibitors. Alternatively, measuring patient response to anti-PD1 therapy in NSCLCs using circRNA and circulating miRNAs has been tested as novel approaches [131,132]. With the ability of circRNA to sponge various miRNA, inducing dysregulation could measure clinical response. As for circulating miRNA, they have the ability to reach various parts of the body and regulate the immune checkpoints, so measuring non-coding RNA expression in patients prior to and during treatment could determine how effective anti-PD1 therapy is. Peng and colleagues reported the strong correlation between immune checkpoints PD1 and CTLA4 with lncRNA MIR155HG, which could potentially serve as models for testing the immune inhibitors prior to clinical trial [184]. Although no other lncRNAs have been shown to have a role in evasion of immune response in lung cancer like HOTAIRM1 and MIR155HG, Denaro et al. created a comprehensive list detailing the role of lncRNAs in other cancers [185]. Thus, it is valuable to study if some lncRNAs play roles in evasion of host immune system in lung cancer.

\subsubsection{Role of Non-Coding RNA in Drug Tolerance and Resistance}

As previously illustrated, a variety of drugs are available today to treat NSCLC and SCLC, but tumor cells have the unique ability to become drug tolerant and resistant to promote their progression. 
Activation of EGFR and MET led to upregulation of miR-221/222 and miR-30b/c (Table 1) [100]. Direct repression of apoptotic peptidase activating factor 1 (APAF1) by miR-221/222 and inhibition of BCL2 like 11 (BIM) by miR-30b/c leads to gefitinib resistance in NSCLC [100]. Similarly, MET induced downregulation of miR-103 and miR-203, promotes resistance to EGFR TKI gefitinib via increasing expression of protein kinase C-epsilon, SRC proto-oncogene, non-receptor tyrosine kinase (SRC) and endoribonuclease Dicer [100]. miR-21 upregulation has been found to downregulate PTEN expression during gefitinib treatment, which led to the activation of the phosphoinositide 3-kinase/protein kinase $\mathrm{B}$ and mitogen-activated protein kinase/extracellular signal-regulated kinase signaling pathways, known pathways involved in gefitinib resistance in NSCLC tumor cells [101]. Recently, it was reported that upregulated miR-147b in EGFR mutant lung adenocarcinoma cells mediates drug tolerance to EGFR TKI osimertinib via repression of Von Hippel-Lindau (VHL) and succinate dehydrogenase (SDH) [102]. Upregulation of HOXA cluster antisense RNA 3 (HOXA-AS3) in NSCLC confers drug resistance to cisplatin-based chemotherapy via downregulating HOXA3 expression (Table 2) [115]. Additionally, hypoxia-induced miR-155 overexpression leads to enhanced resistance to radiotherapy via downregulating forkhead box O3 (FOXO3A), a tumor suppressor that when unphosphorylated induces apoptosis in tumor cells [103]. In NSCLC tissues, upregulated circFGFR1 expression promotes tumor cells progression and resistance to anti-PD1-based immunotherapy. circFGFR1 directly represses miR-381-3p leading to upregulation of C-X-C motif chemokine receptor 4 (CXCR4) [131,132]. Therefore, non-coding RNA-mediated drug tolerance and resistance need to be investigated in the future.

\subsection{Role of Non-Coding RNAs and Metabolism in Lung Cancer}

For cancer to effectively initiate proliferation and tumorigenicity, various metabolic pathways are altered to support the needs of the cancer cells. When studying the metabolism in lung cancer, there are distinct signaling pathways including apoptotic, growth promoting, and growth inhibiting that must be considered [186]. Out of these pathways the most notable are EGFR, MET, PI3K/Akt/mTOR, Ras/Raf/Mitogen-activated protein kinase/ERK kinase (MEK)/extracellular-signal-regulated kinase (ERK), and Wnt/ $\beta$-catenin [187] (Table 3; Figure 2). As a result, non-coding RNAs affecting the cell signaling pathways also have a role in regulation of different cell metabolism cycles including glycolysis, pentose phosphate pathway (PPP), tricarboxylic acid cycle (TCA), and lipid synthesis. Targeting of the enzymes within these metabolic cycles by non-coding RNAs has been reported, which could suggest alteration of cellular processes by controlling non-coding RNA regulation. miR-125a and miR-143 have been reported to target the glycolytic enzyme hexokinase 2 (HK2) by downregulation [188]. As for lactate dehydrogenase A, an enzyme in glycolysis responsible for imitation of lactate production, has targets serving as negative regulators include miR-200c [189], miR-33b [190], and miR-449a [191]. Additionally, IncRNA CRYBG3 overexpression has been reported to be associated with LDHA upregulation [192]. Glycolysis harbors another important pathway known as the PPP. Singh et al. looked at regulation of miR-1 and miR-206 by nuclear factor erythroid-2-related factor 2 (NRF2) which serves as a tumor initiator once activated [193]. Once these miRNAs are regulated, progression of the PPP and TCA cycling can occur. As for the TCA cycle, enzymes such as succinate dehydrogenase $(\mathrm{SDH})$, isocitrate dehydrogenase (IDH), and malate dehydrogenase (MDH) have been identified as targets for various miRNAs (Figure 3). Upregulation of miR-147b repressed enzymatic activity of SDH, initiating a pseudohypoxia signaling response [102]. Similarly, upregulation of miR-210 decreased enzymatic activity of SDHD and furthered activity of HIF-1 $\alpha$ [194]. This idea of adaptation to stress environments is also present via miR-183 and IDH2 regulation [195]. Vohwinkel et al. compared IDH2 response to elevated $\mathrm{CO}_{2}$ with IDH2 response to upregulated miR-183 in epithelial lung cancer cells and found that both downregulated IDH2 [195]. The adaptation of cancer cells to the stress environment by reprogramming metabolic processes could serve as a leading cause of witnessed therapeutic resistance, furthering cancer's progression. Complexes, such as the miR-182-PDK4 axis, have been reported to regulate pyruvate dehydrogenase which is an essential part of TCA cycling and lipogenesis [196]. Other important targets include miR-22 downregulation on ATP citrate lyase (ACLY), which allowed 
for ACLY-mediated lipogenesis and caused increased metastatic effects [197]. Enzymatic activity of MDH1 can be altered as well with miR-126-5p in NSCLC, and with greater doses initiated cell toxicity [198]. The role of non-coding RNAs as regulators in a variety of pathways makes them an important part of studying tumor initiation and progression.

Table 3. Non-coding RNAs that affect cell signaling and metabolic pathways.

\begin{tabular}{|c|c|c|c|c|c|}
\hline $\begin{array}{c}\text { Name of } \\
\text { ncRNA }\end{array}$ & $\begin{array}{l}\text { Type of } \\
\text { ncRNA }\end{array}$ & Targets & Signaling Pathway & Metabolic Pathway & References \\
\hline miR-21 & miRNA & PTEN & $\begin{array}{l}\text { Ras/Raf/MEK/ERK, } \\
\text { PI3K/Akt/mTOR }\end{array}$ & $\begin{array}{c}\text { Glycolysis, } \\
\text { Glucose-mediated TCA } \\
\text { Cycle }\end{array}$ & [101] \\
\hline miR-147b & miRNA & VHL, SDH & EGFR & ETC, TCA Cycle & [102] \\
\hline miR-34a & miRNA & EGFR & $\begin{array}{l}\text { Ras/Raf/MEK/ERK, } \\
\text { PI3K/Akt/mTOR }\end{array}$ & Glycolysis & [199] \\
\hline miR-329 & miRNA & MET & $\begin{array}{l}\text { Ras/Raf/MEK/ERK, } \\
\text { PI3K/Akt/mTOR }\end{array}$ & N.A. & [200] \\
\hline miR-139-5p & miRNA & MET & $\begin{array}{l}\text { Ras/Raf/MEK/ERK, } \\
\text { PI3K/Akt/mTOR }\end{array}$ & N.A. & [201] \\
\hline $\mathrm{miR}-206$ & miRNA & MET & $\begin{array}{l}\text { Ras/Raf/MEK/ERK, } \\
\text { PI3K/Akt/mTOR }\end{array}$ & N.A. & [202] \\
\hline miR-148a-3p & miRNA & SOS2 & Ras/Raf/MEK/ERK & N.A. & [203] \\
\hline miR-193a-3p & miRNA & KRAS & Ras/Raf/MEK/ERK & N.A. & {$[204,205]$} \\
\hline miR-181a-5p & miRNA & KRAS & Ras/Raf/MEK/ERK & N.A. & [206] \\
\hline miR-30c & miRNA & BID, NF1 & Ras/Raf/MEK/ERK & $\begin{array}{l}\text { Glucose-mediated TCA } \\
\text { Cycle }\end{array}$ & [207] \\
\hline Orilnc1 & IncRNA & N.A. & Ras/Raf/MEK/ERK & N.A. & [208] \\
\hline miR-494-3p & miRNA & PTEN & PI3K/Akt/mTOR & Glycolysis & [85] \\
\hline miR-19a & miRNA & MET & PI3K/Akt/mTOR & N.A. & [209] \\
\hline miR-409-3p & miRNA & MET & PI3K/Akt/mTOR & N.A. & [210] \\
\hline ROR & IncRNA & N.A. & PI3K/Akt/mTOR & Glycolysis & [211] \\
\hline miR-142-3p & miRNA & HMGB1 & PI3K/Akt/mTOR & Glycolysis & [212] \\
\hline miR-221 & miRNA & PTEN & PI3K/Akt/mTOR & Glycolysis & [213] \\
\hline miR-124 & miRNA & GLUT1, HK2 & PI3K/Akt/mTOR & Glycolysis & [214] \\
\hline miR-182 & miRNA & HIF1AN & PI3K/Akt/mTOR & ETC, TCA Cycle & [215] \\
\hline IncRNA-NEF & lncRNA & GLUT1 & PI3K/Akt/mTOR & Glycolysis & [216] \\
\hline miR-145-3p & miRNA & PDK1 & PI3K/Akt/mTOR & N.A. & [217] \\
\hline $\mathrm{miR}-487 \mathrm{~b}$ & miRNA & $\begin{array}{l}\text { KRAS, Wnt5a, } \\
\text { MYC }\end{array}$ & Wnt $/ \beta$-Catenin & N.A. & [218] \\
\hline miR-203 & miRNA & FZD2 & Wnt $/ \beta$-Catenin & N.A. & [219] \\
\hline miR-548b & miRNA & CCNB1 & Wnt $/ \beta$-Catenin & N.A. & [220] \\
\hline miR-374a & miRNA & Wnt5a & Wnt $/ \beta$-Catenin & N.A. & [220] \\
\hline AK126698 & lncRNA & FZD8 & Wnt $/ \beta$-Catenin & ETC & [221] \\
\hline LINC00673-v4 & IncRNA & DDX3 & Wnt $/ \beta$-Catenin & N.A. & [222] \\
\hline miR-660 & miRNA & MDM2 & p53 & N.A. & [223] \\
\hline miR-98miR-453 & miRNA & TP53 & p53 & N.A. & [224] \\
\hline circ-MTO1 & circRNA & miR-17 †QKI-5 & Notch & N.A. & [225] \\
\hline circRNA_103809 & circRNA & $\begin{array}{c}\text { miR-4302 - } \\
\text { ZN121 }\end{array}$ & MYC & N.A. & [140] \\
\hline
\end{tabular}


Table 3. Cont.

\begin{tabular}{cccccc}
\hline $\begin{array}{c}\text { Name of } \\
\text { ncRNA }\end{array}$ & $\begin{array}{c}\text { Type of } \\
\text { ncRNA }\end{array}$ & Targets & Signaling Pathway & Metabolic Pathway & References \\
\hline miR-342-3p & miRNA & E2F1 & MYC & N.A. & [226] \\
\hline miR-451a & miRNA & MYC & MYC & N.A. & [227] \\
\hline PART1 & lncRNA & miR-635 & JAK/STAT & N.A. & [228] \\
\hline miR-135 & miRNA & TRIM16 & JAK/STAT & \\
\hline
\end{tabular}

$\dashv$, inhibition. Abbreviations: AKT serine/threonine kinase (AKT), BH3-interacting domain death agonist (BID), C-X3-C motif chemokine receptor 1 (CX3CR1), DEAD-box helicase 3 X-linked (DDX3), epidermal growth factor receptor (EGFR), E2F transcription factor 1 (E2F1), electron transport chain (ETC), frizzled class receptor 2 (FZD2), frizzled class receptor 8 (FZD8), glucose transporter 1 (GLUT1), hypoxia inducible factor 1 subunit alpha inhibitor (HIF1AN), high mobility group box 1 (HMGB1), janus kinase (JAK), mouse double minute 2 (MDM2), mechanistic target of rapamycin kinase (mTOR), neurofibromin 1 (NF1), prostate androgen-regulated transcript 1 (PART1), phosphoinositide-dependent protein kinase-1 (PDK1), phosphatase and tensin homolog (PTEN), quaking homolog (QKI-5), sirtuin 1 (SIRT1), son of sevenless homolog 2 (SOS2), signal transducer and activator of transcription (STAT), tricarboxylic acid cycle (TCA Cycle), tumor protein p53 (TP53), Wnt family member 5a (Wnt5a), wingless-type (WNT), not available (N.A.).

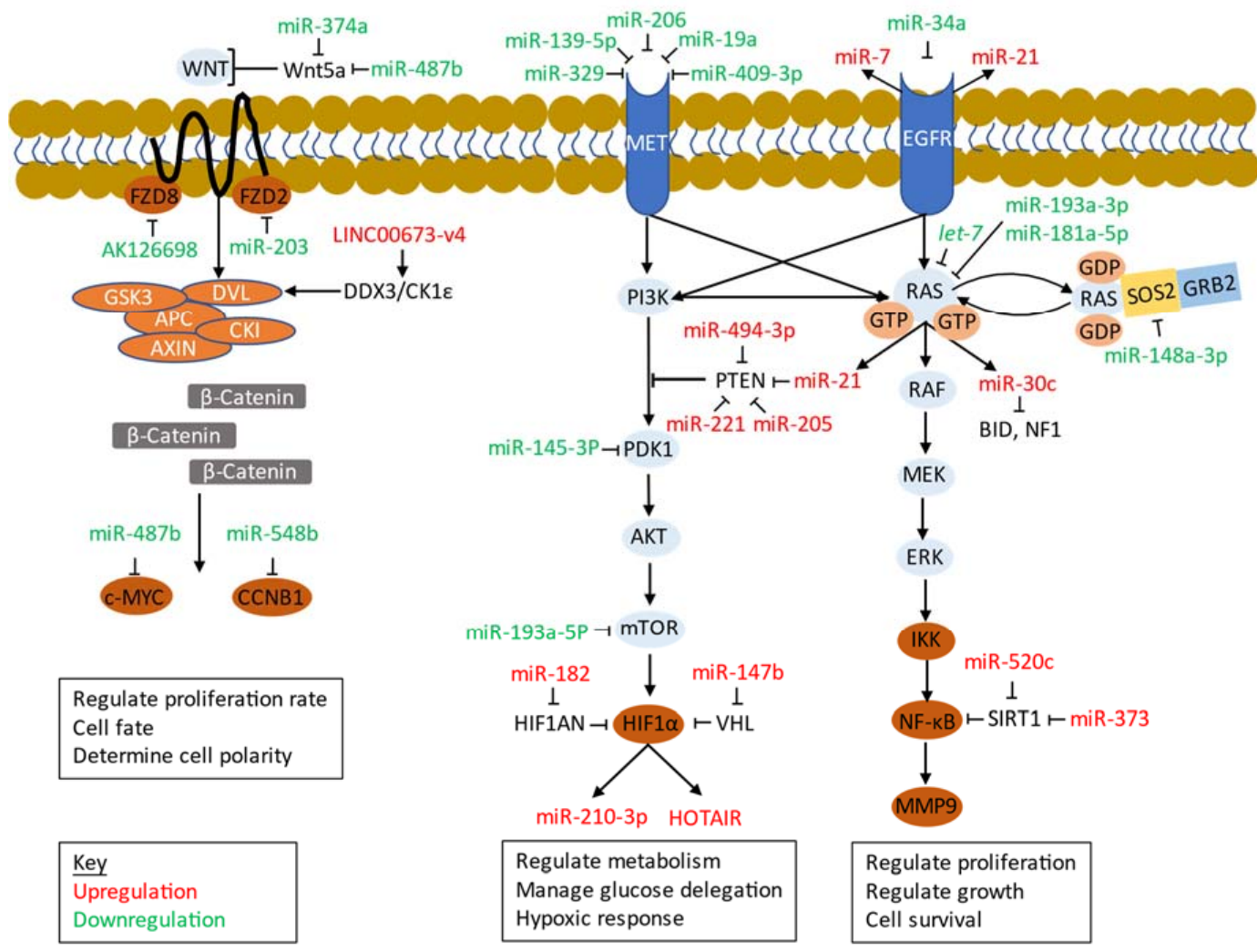

Figure 2. Interactions among cell signaling pathways and non-coding RNAs. $\rightarrow$, promotion; $\dashv$, inhibition; $\curvearrowright / \mathcal{\rho}$, guanine nucleotide exchange reactions. Abbreviations: AKT serine/threonine kinase (AKT), adenomatous polyposis coli (APC), BH3-interacting domain death agonist (BID), cyclin B1 (CCNB1), casein kinase I (CKI), DEAD-box helicase 3 X-linked (DDX3), disheveled (DVL), epidermal growth factor receptor, frizzled class receptor 2 (FZD2), frizzled class receptor 8 (FZD8), glycogen synthase kinase 3 (GSK3), hypoxia inducible factor 1 subunit alpha (HIF1 $\alpha$ ), hypoxia inducible factor 1 subunit alpha inhibitor (HIF1AN), IKB kinase (IKK), matrix metallopeptidase 9 (MMP9), MET proto-oncogene receptor tyrosine kinase (MET), mechanistic target of rapamycin kinase (mTOR), neurofibromin 1 (NF1), nuclear factor kappa-light-chain-enhancer of activated B (NF- $\mathrm{B}$ ), phosphoinositide-dependent protein kinase-1 (PDK1), sirtuin 1 (SIRT1), son of sevenless homolog 2 (SOS2), wingless-type (WNT). 


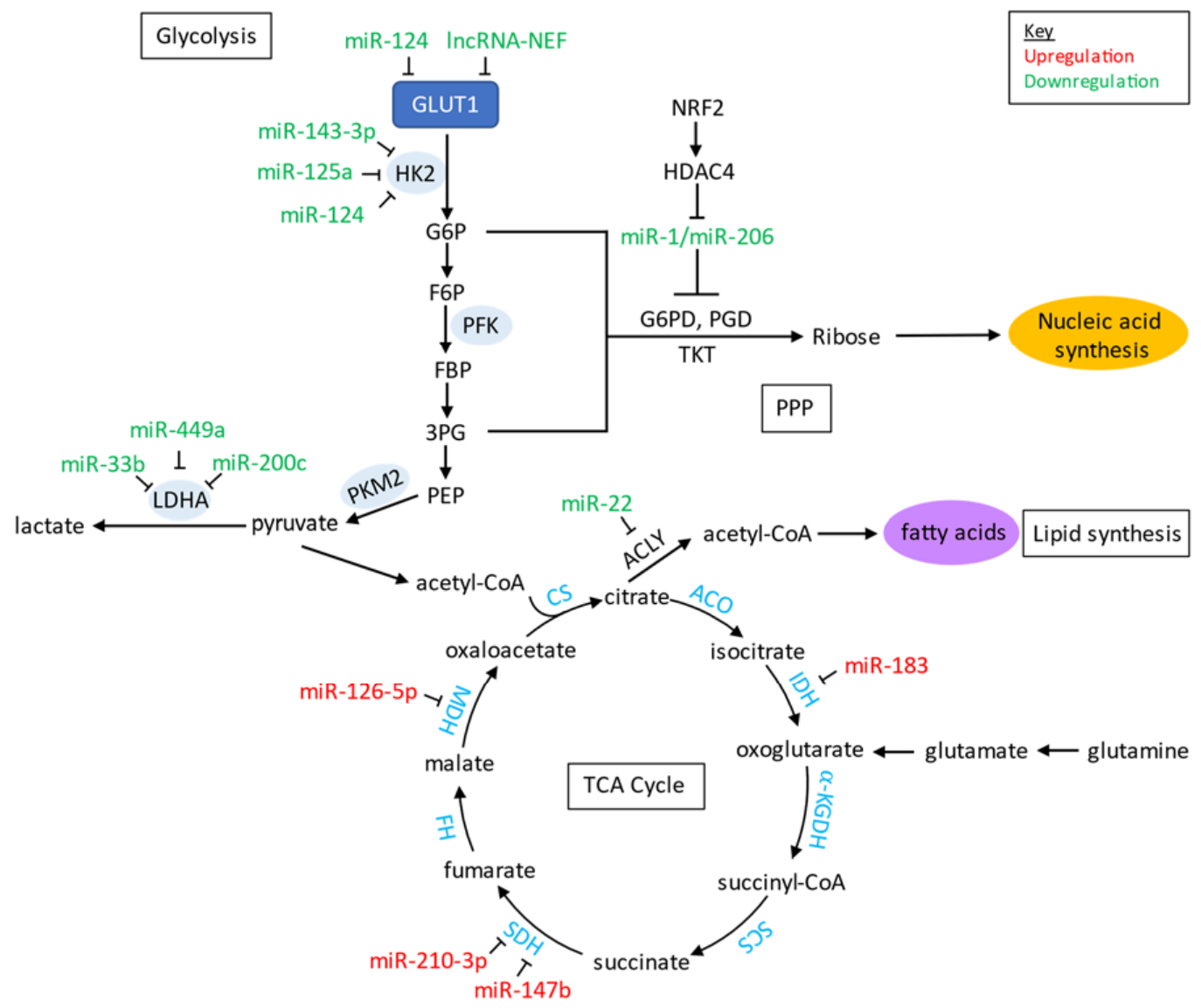

Figure 3. Metabolic pathways including glycolysis, pentose phosphate pathway, tricarboxylic acid cycle, and lipid synthesis with target non-coding RNAs. $\rightarrow$, promotion; $\dashv$, inhibition; $\odot$, metabolic reactions of the tricarboxylic acid cycle. Abbreviations: 3-Phosphoglyceric acid (3PG), AKT serine/threonine kinase (AKT), ATP citrate lyase (ACLY), aconitase (ACO), $\alpha$-Ketoglutarate dehydrogenase ( $\alpha$-KGDH), citrate synthase (CS), fructose 6-phosphate (F6P), fructose bisphosphatase (FBP), fumarase (FH), glucose 6-phosphate (G6P), glucose-6-phosphate dehydrogenase (G6PD), histone deacetylase 4 (HDAC4), glucose transporter 1 (GLUT1), hexokinase 2 (HK2), isocitrate dehydrogenase (IDH), lactate dehydrogenase A (LDHA), malate dehydrogenase (MDH), nuclear factor erythroid-2-related factor 2 (NRF2), phosphoenolpyruvate (PEP), phosphofructokinase-1 (PFK), phosphogluconate dehydrogenase (PGD), pyruvate kinase M1/2 (PKM2), pentose phosphate pathway (PPP), succinyl-CoA synthetase (SCS), succinate dehydrogenase (SDH), transketolase (TKT), wingless-type (WNT).

\subsubsection{EGFR}

EGFR is a transmembrane protein. In different types of cancers, the mutation can occur in different spots and for NSCLC it is in the kinase domain [230]. In order to reduce effect of these mutations, therapies focus on targeting with a tyrosine kinase inhibitor (TKI). Due to the position of EGFR on the cell, it serves as an activator site for multiple signaling pathways including MAPK, PI3K/Akt, and PLC- $\gamma 1-P K C$ [230]. Chou and colleagues found that with the overexpression of miR-7, a miRNA induced by EGFR, demonstrated an increase in cell proliferation and tumor growth rate through the Ras/ERK/Myc pathway [231]. EGFR can be directly targeted by miR-34a through upregulation due to the tumor suppressive abilities of miR-34a [199]. EGFR can also dysregulate non-coding RNAs. miR-21 have shown upregulation in NSCLC, demonstrating how EGFR can function as a regulator for potential tumor progressive non-coding RNAs [232]. Alternatively, regulation of crosstalk between pathways has been noted through miR-205 [233]. Migilore et al. investigated MET-TKI resistance and found that with overexpression of miR-205, a target of ERBB receptor feedback inhibitor 1, induced greater EGFR activity [233]. This could suggest the need for co-targeting of EGFR-associated pathways to prevent 
tumor progression. The targeting of specific non-coding RNAs related to EGFR expression can serve as therapy options in order to inhibit prominent cell signaling pathways present in lung cancer. EGFR has a strong link to glycolysis, which is a precursor to multiple metabolic pathways. Kim et al. looked at how glycolysis was enhanced due to increased glucose uptake and lactate production in order to keep the EGFR mutant NSCLC nourished [234]. As a result of high glucose production, ATP levels were increased which suggests glucose fed TCA cycling [234]. By altering metabolism, cancer cells are able to manage themselves and pursue oncogenic processes, so by targeting of specific receptors or enzymes by non-coding RNAs could inhibit these processes and force cancer cells to find alternative resources or simply die.

\subsubsection{MET}

The MET signaling pathway can be altered through overexpression of MET and/or its ligand the hepatocyte growth factor, and genetic variation of the MET gene, both common in oncogenic processes [235]. Similar to the EGFR, through the activation of MET there are important downstream pathways including MAPK and PI3K that can be activated [236]. Sun and colleagues looked at miR-329 due to its presence in other cancers, and they found that it targets MET to induce negative regulation, which as a result inhibits proliferation and tumorigenesis of NSCLC [200]. Sun et al. has also noted similar findings with miR-139-5p [201] and miR-206 [202]. Others have found that targeting of c-MET with miR-19a [209] and miR-409-3p [210] could inhibit downstream signaling of the Akt signaling pathway as well. Due to crosstalk between KRAS/MET and EGFR/MET, dual targeting of these signaling pathways via non-coding RNAs could potentially predict drug sensitivity, biomarker potential, and prognostic value $[237,238]$.

\subsubsection{PI3K/Akt/mTOR}

The responsibility of this cell signaling pathway is to regulate metabolism and delegate where glucose should be maintained [239]. Initiation of this pathway is through the activation of membrane receptors including tyrosine kinases (TK) such as EGFR, FGFR, HER2, IGFR-1, PDGFR, and VEGFR [240]. Shi and colleagues found that the lncRNA ROR directly inhibits this pathway and could demonstrate increased sensitivity to cisplatin in NSCLC patients [211]. The role of various lncRNA in regard to lung tumor development and progression is still subject for further study. As for the role of miRNA, it was found that the overexpression of miR-296-3p reduced the level of phosphorylation in this pathway without reducing mRNA expression by targeting apurinic/apyrimidinic endodeoxyribonuclease 1 (APEX1), therefore possibly inhibiting the pathway's progression particularly in NSCLC [241]. Additionally, miR-296-3p has been reported to have lower levels of expression in comparison to normal lung epithelial cells, and it played a role in inhibiting NSCLC cell proliferation as well as cisplatin sensitivity by targeting C-X3-C motif chemokine receptor 1(CX3CR1) which is upstream of PI3K signaling [242]. miR-142-3p was found to have an association between the PI3K/Akt/mTOR pathway and high mobility group box 1 (HMBG1) induced autophagy, a process of cellular degradation that if in a high presence can demonstrate conflicting results such as promoting tumor survival versus preventing tumorigenesis [212,243]. In this case, NSCLC autophagy was inhibited via the overexpression of miR-142-3p [212]. Another primary target within the PI3k/Akt/mTOR signaling pathway is PTEN. PTEN is a protein found to terminate hyperactive signaling of PI3K, and the loss of its function has been noted in various human cancers [244]. Common non-coding RNA targets of PTEN in lung carcinoma through upregulation include miR-21 [159], miR-205 [245], miR-221 [213], and miR-494 [85]. With targeting of these specific miRNAs, dependent on whether they deactivate or activate PTEN, can work towards understanding the treatments necessary to regulate the PI3K/Akt/mTOR pathway. Non-coding RNAs targeting Akt signaling can also dysregulate cell metabolism. Makinoshima et al. found that there was a link between the PI3K/Akt/mTOR pathway and aerobic glycolysis as well as maintenance of glucose transporter 1 (GLUT1) through optimal membrane localization specifically in EGFR mutated lung adenocarcinoma cells [246]. GLUTs are responsible for glucose intake and with increased expression 
through this pathway can facilitate increased glycolytic activity such as ATP consumption and ACLY stimulation, essentially serving as a precursor for lipid synthesis [247]. Zhao et al. found that with the overexpression of miR-124, GLUT1, and HK2 expression were reduced [214]. Similarly, it was reported that overexpression of IncRNA-NEF reduced expression of GLUT1, resulting in the inhibition of glucose uptake in NSCLC [216]. Targeting GLUTs by non-coding RNAs could potentially have a role in decreasing tumorigenesis. Another contributing factor to metabolism via PI3K/Akt/mTOR signaling is through HIF- $1 \alpha$, mediated by upstream mTOR [248]. Increased HIF- $1 \alpha$ can initiate tumorigenesis in lung cancer, but by targeting of VHL by miR-147b [102] and HIF1AN by miR-182 [215], regulation can be reduced to prevent this initiation. HIF- $1 \alpha$ can also modulate lncRNA HOTAIR to promote lung tumorigenesis in hypoxic conditions $[249,250]$ and miR-210-3p to prevent HIF- $1 \alpha$ degradation via suppression of SDHD enzymatic activity [194]. Focusing on non-coding RNA markers contributory to glucose metabolism and hypoxic response can help better understand how pathway crosstalk influences cell processes leading to tumorigenesis and progression.

\subsubsection{Ras/Raf/MEK/ERK (MAPK)}

The MAPK signaling pathway consists of a variety of interconnected pathways that work to regulate growth, proliferation, and survival of the cells, initiated by growth factor receptors, similar to that of the PI3K/Akt/mTOR pathway [251]. Through the inhibition of mTOR/mTORC1, the Ras/Raf/MEK/ERK pathway can be activated through Ras [252]. The MAPK pathway can be activated by decreasing mRNA translation in SIRT1 via miR-520c and miR-373 [253]. The crosstalk between the two pathways perhaps demonstrates how multiple pathways become involved in tumorigenesis and proliferation, and by targeting one can reduce activation of the other. Xie and colleagues looked at miR-148a-3p, a tumor growth suppressor found in NSCLC, and found that it had a role in MAPK/ERK inhibition via overexpression which led to decreased presence of son of sevenless homolog 2 (SOS2) and consequently inhibited Ras activation [203]. Alternatively, targeting activated KRAS with overexpression of tumor suppressors miR-193a-3p [204,205] and miR-181a-5p [206,254] could potentially inhibit further progression of tumor growth. Homogenous KRAS G12D mutant, a common mutation causing dysregulation of the MAPK pathway, has been reported to favor glucose fueled TCA cycling due to glucose metabolic reprogramming and reactive oxygen species (ROS) management, leading to increased malignancy [255]. The interplay between miRNA and ROS in cancer treatment response has been discussed in recent reviews $[256,257]$. Non-coding RNAs such as miR-21 and miR-30c have shown upregulation with KRAS G12D overexpression, which as a result enhance regulation of Ras downstream pathways [207]. In contrast, a negative regulator of Ras includes the let-7 family which acts as a tumor suppressive miRNA and inhibits downstream signaling [104]. Alternatively, the expression of non-coding RNAs can be regulated through the signaling pathway itself. As noted by Zhang et al., with the inhibition of the MAPK pathways, expression of Ornlnc1, a highly expressed lncRNA in BRAF mutated cancers, was decreased [208]. As a result, this subsequently reduced cancer cell growth in vivo and in vitro.

\subsubsection{Wnt/ $\beta$-Catenin}

The Wnt/ $\beta$-catenin (canonical) pathway holds the responsibility of determining cell polarity, rate of proliferation, and the fate of the cell [258]. Through this pathway, mutation at and surrounding the $\beta$-catenin site is most common in cancers, but in regard to lung cancer, its distinguishing factor is based on alterations to various Wnt proteins including Wnt-1-5a, frizzled class receptor 8 (FZD8), and the gene $\beta$-catenin $[258,259]$. miR-487b and miR-203 have been noted to work as tumor suppressive miRNAs in lung cancer by targeting KRAS, WNT5A, SUZ12, MYC, and BMI1 (miR-487b) [218] and FZD2 (miR-203) [219]. Targeting of CCNB1 by miR-548b and Wnt5a by miR-374a have also been reported in lung cancer cell lines, with both serving as tumor repressors [220]. Other lncRNAs that work as a suppressor include MEG3, interaction with p53 to downregulate $\beta$-catenin [260], and AK126698, negative regulation of FZD8 [221]. Alternatively, Guan and colleagues found that the overexpression 
of the IncRNA LINC00673-v4 was found to activate the Wnt/ $\beta$-catenin pathway, noted by the enhanced interaction between DDX3 and CK1 $1 \varepsilon$ essentially leading to enhanced signaling of the pathway in lung adenocarcinoma cells [222]. With the overexpression of $\beta$-catenin and $\beta$-catenin transcriptional activity by SDH5 (ETC component) inhibition, cancer metabolism can be altered through the mediation of Wnt EMT and metastasis [261]. $\beta$-catenin activation is mediated through the GSK-3 $\beta$ enzyme which in turn can be altered through targeting by SDH5 [261]. It has been reported that $\mathrm{Wnt} / \beta$-catenin can be regulated through the inactivation of the DVL2-NRX complex formation by elevating ROS $\left(\mathrm{Ca}^{2+}\right.$ mediated), which can additionally cause accumulation of nuclear $\beta$-catenin in human neural progenitor cells $[262,263]$. Accumulation of $\beta$-catenin through glucose has also been reported to enhance the signaling pathway and as a result increase the risk of cancer development [264].

\subsection{Role of Non-Coding RNAs and Pathogens in Lung Cancer}

Due to high exposure rates of pathogens to the lungs, development of NSCLC and SCLC can progress due to resource competition. Conditions such as hepatitis B (HBV), hepatitis C (HCV), Epstein-Barr (EBV), tuberculosis (TB), pneumonia, and other various bacterial/viral infections can lead to such cancer development and progression along with increasing poor clinical outcome.

Although hepatic infections, specifically hepatitis B and C, have been closely associated with hepatocellular cancers, noted links to lung cancer have been identified. Wu et al. performed a meta-analysis highlighting the problem of acquisition of HBV in lung cancer patients on chemotherapy, which interfered with treatment results [265]. Through targeting of these infections using miRNAs, the risk of lung tumor initiation may be reduced. For HBV, Yao and colleagues found that patients that were being treated with EGFR tyrosine kinase inhibitors developed HBV reactivation during treatment [266]. Non-coding RNAs that target HBV by enhancing infection include overexpression of miR-21 [267], miR-501 [268], IncRNA PCNAP1 [269], and reduced expression of miR-122 [270]. Feng et al. also reported that the expression of miR-154, which is a common tumor suppressor in lung cancer, and PCNAP1 are linked and compete [269]. This suggests that miRNAs and lncRNAs can modulate each other to work towards their advantage. Alternatively, HBV-miR-3 [271] and miR-141 [272] have been found to suppress HBV replication. It has been reported that in HCV associated hepatocellular cancers, there was an upregulation of miR-125a-5p [273]. In contrast, miR-125a-5p has been found to be a tumor suppressor and was downregulated in NSCLC [274]. miR-21, a primary target of PTEN in lung cancers, also demonstrated upregulation in human hepatocytes with HCV [275]. Other key HCV targets include miR-196 [276] and miR-122 [277].

EBV has been clinically found in rare NSCLCs including lymphoepithelioma-like carcinoma (LELC) primarily in east Asian individuals $[278,279]$ as well as reports in lung adenocarcinoma and lung squamous cell carcinoma $[280,281]$. Unlike cancers, EBV can encode their own non-coding RNAs that have roles in apoptosis, gene regulation, cell signaling, host-cell immunity, and cancer cell proliferation [282]. These include EB virus-encoded RNAs (EBERs), BamHI-A rightward transcripts (BARTs), viral snoRNA1, EBV-sisRNA-1, and EBV-miRNAs [283]. Movassagh and colleagues reported that out of the tested lung adenocarcinoma and lung squamous cell carcinoma samples the expression of EBV miRNA was 6\% and 12\% respectively [284]. Similarly, high levels of EBV miRNA have not been detected in NSCLC, suggesting that a source of prior infection of EBV in lung cancer patients is the cause for the presence and there is no current associated link between infection and tumorigenesis [285]. The role of EBV noncoding RNAs on varying lung cancers is subject to further study.

The role of pulmonary diseases including pneumonia and TB on lung cancer development have been studied to improve clinical results. However, the coexistence between lung cancer and pulmonary TB have shown conflicting results. These results can be split into categories such as 1 . TB initiating lung cancer development, 2. Reactivation of TB in lung cancer patients and 3. Radiological and physiological similarities between TB and lung cancer [286]. Abd-El-Fattah et al. tested expression of miRNA in serum of lung cancer patients to determine possible association with pulmonary diseases [287]. They found that upregulation of miR-21 and miR-155, both having a role in inflammation rate, could 
serve as a source of $\mathrm{TB}$ and pneumonia, and adjacently high expression levels in patients with pneumonia [287]. Furthermore, testing of the effect of potential pneumonia and TB non-coding RNA biomarkers in comparison to non-coding RNA expression in lung cancers could serve as beneficial for determining future treatment plans.

\section{Cell-Free Circulating Non-Coding RNAs in Lung Cancer}

Circulating non-coding RNAs have been identified as valuable noninvasive biomarkers for early detection and analyzing clinical response due to their presence in human body fluids such as serum, urine, and plasma. Prognostic value and biomarker potential in lung cancer patients have been studied by altering expression levels and measuring established expression levels of miR-21 [288], miR-145 [289], miR-125b [290], miR-182 [291], and miR-19b [292]. In correspondence to drug response, low expression of miR-145 was found to be associated with chemotherapy resistance [289] while downregulation of miR-21 demonstrated better gefitinib response [288]. For long non-coding RNAs, HOTAIR [293], LINC00152 [294], growth arrest-specific transcript 5 (GAS5) [295,296], lncRNA-NEF [216], and SOX2 overlapping transcript (SOX2OT) [296] have been identified as potential biomarkers for lung cancers. With further research on circulating non-coding RNAs in relation to particular cancers, there could possibly be greater early detection using this noninvasive technique. This could account for starting treatments earlier, prolonging length of survival, and monitoring the effectiveness of treatment based on RNA regulation.

\section{Pre-Clinical Models for Human Lung Cancer}

In order to test treatments prior to clinical study, researchers have developed in vivo and in vitro pre-clinical models such as spheroid cultures, organoid cultures, patient derived explants/xenografts, and air-liquid interface models. Spheroid cultures serve as 3-D models that can demonstrate cell aggregation and tumor progression. Kim et al. looked at the role of miR-34 on cancer cell invasion by using spheroid cultures and found that miR-34b/c significantly suppressed spheroid invasion and EMT [297]. Ekert and colleagues compared 3-D spheroid cultures with 2-D monolayer cultures for multiple EGFR wild type and mutated cell lines and found that 3-D spheroids were able to reproduce proliferative processes. However the spheroids had higher basal receptor phosphorylation activity of EGFR and c-MET, and altered therapeutic response in multiple cell lines compared to the 2-D models [298]. Differences in drug response in 3-D models compared to 2-D models has been reported in multiple studies, so properly accounting for these alterations will need to be further evaluated prior to moving towards clinical trial. Alternatively, organoid cultures can also be used as 3-D models. Kim et al. compared 3-D organoids with patient derived models and found that organoids supported differing histology and genetic characteristics of various lung cancer types, however drug response continued to vary in these models similar to spheroids [299]. Similarly, Sachs et al. reported that organoid cultures can maintain cancer-related gene mutations, both apoptotic and proliferating [300]. Due to limited current data, future study of targeting common cancer initiating genes with non-coding RNAs using organoid models could serve as promising indicators for clinical therapeutic response and tumorigenesis. A form of in vitro modeling includes air-liquid interface models, which attempt to mimic the microenvironment of the lungs [301]. Movia et al. utilized these multilayered cultures to test response chemotherapy administered through inhalation and they found that these models demonstrated high chemoresistance [301]. Further study of therapeutic efficacy using miRNAs by mimicking the lung microenvironment with air-liquid interface models could serve as promising future study.

\section{Clinical Trial of Lung Cancer}

Although there have been many reported clinical trials involving non-coding RNAs as early detection biomarkers and diagnostic indicators, there are few involving non-coding RNAs and treatment [302]. The first approved miRNA target therapy was MRX34, which is a 
miR-34a mimic, utilized on hepatocellular carcinoma, lung cancer and others with hepatic metastasis (NCT01829971) [303]. With this clinical trial, feasibility of non-coding RNAs as potential therapies was confirmed. In a trial from The Asbestos Diseases Research Institute (NCT02369198), looked at the linkage of miRNA expression with malignant pleural mesothelioma, a rare type of lung cancer [304]. Using this study, they test miRNAs from the miR-15 family and drug sensitivity to determine whether treatment with altering regulation of non-coding RNAs would be beneficial for long term treatment. To accomplish this, they utilized synthetic miRNA known as TargomiRs, specifically a miR-16 mimic. Out of the 26 individuals who participated, only one demonstrated a partial response to the treatment. In another clinical study by Berghmans et al., patients with NSCLC were tested with combination chemotherapy treatment Cisplatin and Vinorelbine [305]. They attempted to determine if mRNA and miRNA could be determinant biomarkers for prognostic value. Comparing transcriptomic analyses from previous study of potential miRNA biomarkers [306] versus actual expression in the patients did not demonstrate clear results. With limitations due to varying histology of lung cancers and isolation of miRNA expression, determining clear biomarkers is difficult for researchers to identify. As progression of therapy using non-coding RNAs in 3-D models persist, there will be anticipation for more clinical trials. At this current stage, involvement of non-coding RNAs as promising therapies is unknown.

\section{Concluding Remarks and Future Direction}

Through our analysis of research regarding non-coding RNAs we found that there is indeed a link between miRNAs and lncRNAs with lung tumor initiation and progression. However, further research is needed, especially in regard to lncRNAs. It is imperative that lncRNAs are studied to further our understanding of their mechanisms of action within lung cancer, especially since lncRNAs and miRNAs have been found to affect each other and lung cancer overall, as exemplified by RNA component of mitochondrial RNA processing endoribonuclease being able to affect miR-206 levels to activate oncogenes in lung cancer (see Table 2). As shown before, literature reviews such as "Long noncoding RNAs as regulators of cancer immunity" have summarized the role of non-coding RNAs in other types of cancers, and researchers can use this information to determine whether those non-coding RNAs are also able to affect lung cancer $[89,163,185]$. Furthermore, new and emerging technologies such as RNA editing and RNA modification warrant further research as they too have been implicated in altering lncRNAs and miRNAs to either promote or impede lung tumor initiation and progression. Altogether, the aforementioned challenges must be addressed in order to decrease the perverse effects of lung cancer, especially since traditional therapeutic methods employed to obstruct lung cancer, such as chemotherapy and targeted therapy (e.g., EGFR TKIs) have in part been made obsolete by the expression of non-coding RNAs. Due to emerging understanding of cell signaling/metabolic mechanisms, catering target therapy to noninvasive methods such as altering non-coding RNA expression or indicating specific biomarkers (e.g., circulating non-coding RNAs) could serve as new effective methods [307]. While most of the past clinical studies focused on non-coding RNAs as diagnostic markers, new emerging clinical trials are moving towards understanding how non-coding RNAs can be used as prognostic and clinical response markers [308]. Using computer science-based artificial intelligence [309], models can be created to predict dysregulation in different microenvironments. Limitations include coming up with a standardized collection of specific biomarkers due to differing histology in various cancer types, but using artificial intelligence could potentially source various databases and isolate the most effective non-coding RNAs. Not only is there a challenge with differing histology and microenvironments, but non-coding RNAs can be regulated differently between immune cells, tumor cells, and cells from other cancers. A potential way to combat this is by utilizing crosstalk between lncRNA/miRNA, miRNA/miRNA, or IncRNA/IncRNA modulation, similar to combination therapy. With more advanced clinical models that mimic the lung tumor microenvironment, the value non-coding RNAs and therapeutic treatment can be monitored and hopefully move towards more clinical trials. 
Author Contributions: Conceptualization, R.M.S., C.M., W.C.Z.; methodology, R.M.S. and C.M.; software, R.M.S. and C.M.; formal analysis, R.M.S. and C.M.; resources, R.M.S. and C.M.; data curation, R.M.S. and C.M.; writing—original draft preparation, R.M.S., C.M., W.C.Z.; writing—review and editing, R.M.S., C.M., W.C.Z.; visualization, R.M.S. and C.M.; supervision, W.C.Z.; project administration, W.C.Z; funding acquisition, W.C.Z. All authors have read and agreed to the published version of the manuscript.

Funding: This research was funded by the Burnett School of Biomedical Sciences, College of Medicine, University of Central Florida grant 25400714 awarded to W.C.Z. Zhang's research is supported in part by a Young Investigator Award from the International Lung Cancer Foundation.

Acknowledgments: We thank Robert Burns and Joshua Roney for critical reading and comments. We apologize to all researches whose work could not be cited due to reference limitations.

Conflicts of Interest: The authors declare no conflict of interest.

\section{References}

1. Torre, L.A.; Bray, F.; Siegel, R.L.; Ferlay, J.; Lortet-Tieulent, J.; Jemal, A. Global cancer statistics, 2012. CA Cancer J. Clin. 2015, 65, 87-108. [CrossRef] [PubMed]

2. Siegel, R.L.; Miller, K.D.; Jemal, A. Cancer statistics, 2020. CA Cancer J. Clin. 2020, 70, 7-30. [CrossRef] [PubMed]

3. Gazdar, A.F.; Bunn, P.A.; Minna, J.D. Small-cell lung cancer: What we know, what we need to know and the path forward. Nat. Rev. Cancer 2017, 17, 725-737. [CrossRef] [PubMed]

4. Greenlee, R.T.; Murray, T.; Bolden, S.; Wingo, P.A. Cancer statistics, 2000. CA Cancer J. Clin. 2000, 50, 7-33. [CrossRef] [PubMed]

5. Ricciuti, B.; Mecca, C.; Crinò, L.; Baglivo, S.; Cenci, M.; Metro, G. Non-coding RNAs in lung cancer. Oncoscience 2014, 1, 674-705. [CrossRef] [PubMed]

6. Macfarlane, L.-A.; Murphy, P.R. MicroRNA: Biogenesis, Function and Role in Cancer. Curr. Genom. 2010, 11, 537-561. [CrossRef]

7. Herbst, R.S.; Heymach, J.V.; Lippman, S.M. Lung Cancer. New Engl. J. Med. 2008, 359, 1367-1380. [CrossRef]

8. Bhattacharjee, A.; Richards, W.G.; Staunton, J.; Li, C.; Monti, S.; Vasa, P.; Ladd, C.; Beheshti, J.; Bueno, R.; Gillette, M.; et al. Classification of human lung carcinomas by mRNA expression profiling reveals distinct adenocarcinoma subclasses. Proc. Natl. Acad. Sci. USA 2001, 98, 13790-13795. [CrossRef]

9. Campling, B.G.; el-Deiry, W.S. Clinical implications of p53 mutations in lung cancer. Methods Mol. Med. 2003, 75, 53-77. [CrossRef]

10. Remen, T.; Pintos, J.; Abrahamowicz, M.; Siemiatycki, J. Risk of lung cancer in relation to various metrics of smoking history: A case-control study in Montreal. BMC Cancer 2018, 18, 1275. [CrossRef]

11. Horn, L.; Mansfield, A.S.; Szczęsna, A.; Havel, L.; Krzakowski, M.; Hochmair, M.J.; Huemer, F.; Losonczy, G.; Johnson, M.L.; Nishio, M.; et al. First-Line Atezolizumab plus Chemotherapy in Extensive-Stage Small-Cell Lung Cancer. N. Engl. J. Med. 2018, 379, 2220-2229. [CrossRef] [PubMed]

12. Paz-Ares, L.; Dvorkin, M.; Chen, Y.; Reinmuth, N.; Hotta, K.; Trukhin, D.; Statsenko, G.; Hochmair, M.J.; Özgüroğlu, M.; Ji, J.H.; et al. Durvalumab plus platinum-etoposide versus platinum-etoposide in first-line treatment of extensive-stage small-cell lung cancer (CASPIAN): A randomised, controlled, open-label, phase 3 trial. Lancet 2019, 394, 1929-1939. [CrossRef]

13. Miller, K.; Nogueira, L.; Mariotto, A.; Rowland, J.; Yabroff, R.; Alfano, C.; Jemal, A.; Kramer, J.; Siegel, R. Cancer treatment and survivorship statistics, 2019. CA 2019, 69. [CrossRef]

14. Herbst, R.S.; Schlessinger, J. Small molecule combats cancer-causing KRAS protein at last. Nature 2019, 575, 294-295. [CrossRef]

15. Yang, H.; Liang, S.Q.; Schmid, R.A.; Peng, R.W. New Horizons in. Front. Oncol. 2019, 9, 953. [CrossRef]

16. Canon, J.; Rex, K.; Saiki, A.Y.; Mohr, C.; Cooke, K.; Bagal, D.; Gaida, K.; Holt, T.; Knutson, C.G.; Koppada, N.; et al. The clinical KRAS(G12C) inhibitor AMG 510 drives anti-tumour immunity. Nature 2019, 575, 217-223. [CrossRef] [PubMed]

17. Lanman, B.A.; Allen, J.R.; Allen, J.G.; Amegadzie, A.K.; Ashton, K.S.; Booker, S.K.; Chen, J.J.; Chen, N.; Frohn, M.J.; Goodman, G.; et al. Discovery of a Covalent Inhibitor of KRAS(G12C) (AMG 510) for the Treatment of Solid Tumors. J. Med. Chem. 2020, 63, 52-65. [CrossRef] [PubMed] 
18. Papadopoulos, K.P.; Ou, S.-H.I.; Johnson, M.L.; Christensen, J.; Velastegui, K.; Potvin, D.; Faltaos, D.; Chao, R.C. A phase I/II multiple expansion cohort trial of MRTX849 in patients with advanced solid tumors with KRAS G12C mutation. J. Clin. Oncol. 2019, 37, TPS3161. [CrossRef]

19. Hallin, J.; Engstrom, L.D.; Hargis, L.; Calinisan, A.; Aranda, R.; Briere, D.M.; Sudhakar, N.; Bowcut, V.; Baer, B.R.; Ballard, J.A.; et al. The KRAS(G12C) Inhibitor MRTX849 Provides Insight toward Therapeutic Susceptibility of KRAS-Mutant Cancers in Mouse Models and Patients. Cancer Discov. 2020, 10, 54-71. [CrossRef]

20. Nagasaka, M.; Li, Y.; Sukari, A.; Ou, S.I.; Al-Hallak, M.N.; Azmi, A.S. KRAS G12C Game of Thrones, which direct KRAS inhibitor will claim the iron throne? Cancer Treat. Rev. 2020, 84, 101974. [CrossRef]

21. Therasse, P.; Arbuck, S.G.; Eisenhauer, E.A.; Wanders, J.; Kaplan, R.S.; Rubinstein, L.; Verweij, J.; Van Glabbeke, M.; van Oosterom, A.T.; Christian, M.C.; et al. New guidelines to evaluate the response to treatment in solid tumors. European Organization for Research and Treatment of Cancer, National Cancer Institute of the United States, National Cancer Institute of Canada. J. Natl. Cancer Inst. 2000, 92, 205-216. [CrossRef] [PubMed]

22. Morrison, B.J.; Morris, J.C.; Steel, J.C. Lung cancer-initiating cells: A novel target for cancer therapy. Target. Oncol. 2013, 8, 159-172. [CrossRef]

23. Clarke, M.F.; Dick, J.E.; Dirks, P.B.; Eaves, C.J.; Jamieson, C.H.; Jones, D.L.; Visvader, J.; Weissman, I.L.; Wahl, G.M. Cancer stem cells-perspectives on current status and future directions: AACR Workshop on cancer stem cells. Cancer Res. 2006, 66, 9339-9344. [CrossRef]

24. Hardavella, G.; George, R.; Sethi, T. Lung cancer stem cells-characteristics, phenotype. Transl. Lung Cancer Res. 2016, 5, 272-279. [CrossRef]

25. Eramo, A.; Lotti, F.; Sette, G.; Pilozzi, E.; Biffoni, M.; Di Virgilio, A.; Conticello, C.; Ruco, L.; Peschle, C.; De Maria, R. Identification and expansion of the tumorigenic lung cancer stem cell population. Cell Death Differ. 2008, 15, 504-514. [CrossRef] [PubMed]

26. Zhang, W.C.; Shyh-Chang, N.; Yang, H.; Rai, A.; Umashankar, S.; Ma, S.; Soh, B.S.; Sun, L.L.; Tai, B.C.; Nga, M.E.; et al. Glycine decarboxylase activity drives non-small cell lung cancer tumor-initiating cells and tumorigenesis. Cell 2012, 148, 259-272. [CrossRef] [PubMed]

27. Zheng, Y.; de la Cruz, C.C.; Sayles, L.C.; Alleyne-Chin, C.; Vaka, D.; Knaak, T.D.; Bigos, M.; Xu, Y.; Hoang, C.D.; Shrager, J.B.; et al. A rare population of CD24(+)ITGB4(+)Notch(hi) cells drives tumor propagation in NSCLC and requires Notch3 for self-renewal. Cancer Cell 2013, 24, 59-74. [CrossRef]

28. Yang, L.; Shi, P.; Zhao, G.; Xu, J.; Peng, W.; Zhang, J.; Zhang, G.; Wang, X.; Dong, Z.; Chen, F.; et al. Targeting cancer stem cell pathways for cancer therapy. Signal. Transduct. Target. Ther. 2020, 5, 8. [CrossRef]

29. Phi, L.T.H.; Sari, I.N.; Yang, Y.-G.; Lee, S.-H.; Jun, N.; Kim, K.S.; Lee, Y.K.; Kwon, H.Y. Cancer Stem Cells (CSCs) in Drug Resistance and their Therapeutic Implications in Cancer Treatment. Stem Cells Int. 2018, 2018, 5416923. [CrossRef]

30. Prieto-Vila, M.; Takahashi, R.-U.; Usuba, W.; Kohama, I.; Ochiya, T. Drug Resistance Driven by Cancer Stem Cells and Their Niche. Int. J. Mol. Sci. 2017, 18, 2574. [CrossRef]

31. Sun, Y.-L.; Patel, A.; Kumar, P.; Chen, Z.-S. Role of ABC transporters in cancer chemotherapy. Chin. J. Cancer 2012, 31, 51-57. [CrossRef] [PubMed]

32. Tan, Y.; Chen, B.; Xu, W.; Zhao, W.; Wu, J. Clinicopathological significance of CD133 in lung cancer: A meta-analysis. Mol. Clin. Oncol. 2014, 2, 111-115. [CrossRef] [PubMed]

33. Plaks, V.; Kong, N.; Werb, Z. The cancer stem cell niche: How essential is the niche in regulating stemness of tumor cells? Cell Stem Cell 2015, 16, 225-238. [CrossRef] [PubMed]

34. Ramirez, R.D.; Sheridan, S.; Girard, L.; Sato, M.; Kim, Y.; Pollack, J.; Peyton, M.; Zou, Y.; Kurie, J.M.; Dimaio, J.M.; et al. Immortalization of human bronchial epithelial cells in the absence of viral oncoproteins. Cancer Res. 2004, 64, 9027-9034. [CrossRef] [PubMed]

35. Counter, C.M. The roles of telomeres and telomerase in cell life span. Mutat. Res. 1996, 366, 45-63. [CrossRef]

36. Smith, J.L.; Lee, L.C.; Read, A.; Li, Q.; Yu, B.; Lee, C.-S.; Luo, J. One-step immortalization of primary human airway epithelial cells capable of oncogenic transformation. Cell Biosci. 2016, 6, 57. [CrossRef]

37. Jafri, M.A.; Ansari, S.A.; Alqahtani, M.H.; Shay, J.W. Roles of telomeres and telomerase in cancer, and advances in telomerase-targeted therapies. Genome Med. 2016, 8, 69. [CrossRef] 
38. Lundberg, A.S.; Randell, S.H.; Stewart, S.A.; Elenbaas, B.; Hartwell, K.A.; Brooks, M.W.; Fleming, M.D.; Olsen, J.C.; Miller, S.W.; Weinberg, R.A.; et al. Immortalization and transformation of primary human airway epithelial cells by gene transfer. Oncogene 2002, 21, 4577-4586. [CrossRef]

39. Sussan, T.E.; Pletcher, M.T.; Murakami, Y.; Reeves, R.H. Tumor suppressor in lung cancer 1 (TSLC1) alters tumorigenic growth properties and gene expression. Mol. Cancer 2005, 4, 28. [CrossRef] [PubMed]

40. Inamura, K. Lung Cancer: Understanding Its Molecular Pathology and the 2015 WHO Classification. Front. Oncol. 2017, 7, 193. [CrossRef] [PubMed]

41. Teixeira, V.H.; Pipinikas, C.P.; Pennycuick, A.; Lee-Six, H.; Chandrasekharan, D.; Beane, J.; Morris, T.J.; Karpathakis, A.; Feber, A.; Breeze, C.E.; et al. Deciphering the genomic, epigenomic, and transcriptomic landscapes of pre-invasive lung cancer lesions. Nat. Med. 2019, 25, 517-525. [CrossRef] [PubMed]

42. Lo Sardo, F.; Strano, S.; Blandino, G. YAP and TAZ in Lung Cancer: Oncogenic Role and Clinical Targeting. Cancers 2018, 10, 137. [CrossRef] [PubMed]

43. George, J.; Lim, J.S.; Jang, S.J.; Cun, Y.; Ozretić, L.; Kong, G.; Leenders, F.; Lu, X.; Fernández-Cuesta, L.; Bosco, G.; et al. Comprehensive genomic profiles of small cell lung cancer. Nature 2015, 524, 47-53. [CrossRef] [PubMed]

44. Gibbons, D.L.; Byers, L.A.; Kurie, J.M. Smoking, p53 mutation, and lung cancer. Mol. Cancer Res. 2014, 12, 3-13. [CrossRef]

45. Zandi, R.; Larsen, A.B.; Andersen, P.; Stockhausen, M.T.; Poulsen, H.S. Mechanisms for oncogenic activation of the epidermal growth factor receptor. Cell Signal. 2007, 19, 2013-2023. [CrossRef]

46. Bethune, G.; Bethune, D.; Ridgway, N.; Xu, Z. Epidermal growth factor receptor (EGFR) in lung cancer: An overview and update. J. Thorac. Dis. 2010, 2, 48-51.

47. Peitzsch, C.; Tyutyunnykova, A.; Pantel, K.; Dubrovska, A. Cancer stem cells: The root of tumor recurrence and metastases. Semin. Cancer Biol. 2017, 44, 10-24. [CrossRef]

48. Shiozawa, Y.; Nie, B.; Pienta, K.J.; Morgan, T.M.; Taichman, R.S. Cancer stem cells and their role in metastasis. Pharmacol. Ther. 2013, 138, 285-293. [CrossRef]

49. Celià-Terrassa, T.; Kang, Y. Distinctive properties of metastasis-initiating cells. Genes Dev. 2016, 30, 892-908. [CrossRef]

50. Singh, M.; Venugopal, C.; Tokar, T.; McFarlane, N.; Subapanditha, M.K.; Qazi, M.; Bakhshinyan, D.; Vora, P.; Murty, N.K.; Jurisica, I.; et al. Therapeutic Targeting of the Premetastatic Stage in Human Lung-to-Brain Metastasis. Cancer Res. 2018, 78, 5124-5134. [CrossRef]

51. Lehuédé, C.; Dupuy, F.; Rabinovitch, R.; Jones, R.G.; Siegel, P.M. Metabolic Plasticity as a Determinant of Tumor Growth and Metastasis. Cancer Res. 2016, 76, 5201-5208. [CrossRef] [PubMed]

52. Popper, H.H. Progression and metastasis of lung cancer. Cancer Metastasis Rev. 2016, 35, 75-91. [CrossRef] [PubMed]

53. Hall, R.D.; Le, T.M.; Haggstrom, D.E.; Gentzler, R.D. Angiogenesis inhibition as a therapeutic strategy in non-small cell lung cancer (NSCLC). Transl. Lung Cancer Res. 2015, 4, 515-523. [CrossRef] [PubMed]

54. Muz, B.; de la Puente, P.; Azab, F.; Azab, A.K. The role of hypoxia in cancer progression, angiogenesis, metastasis, and resistance to therapy. Hypoxia 2015, 3, 83-92. [CrossRef] [PubMed]

55. Lv, X.; Li, J.; Zhang, C.; Hu, T.; Li, S.; He, S.; Yan, H.; Tan, Y.; Lei, M.; Wen, M.; et al. The role of hypoxia-inducible factors in tumor angiogenesis and cell metabolism. Genes Dis. 2016, 4, 19-24. [CrossRef] [PubMed]

56. Eliasz, S.; Liang, S.; Chen, Y.; De Marco, M.A.; Machek, O.; Skucha, S.; Miele, L.; Bocchetta, M. Notch-1 stimulates survival of lung adenocarcinoma cells during hypoxia by activating the IGF-1R pathway. Oncogene 2010, 29, 2488-2498. [CrossRef]

57. Pal, M.; Chen, H.; Lee, B.H.; Lee, J.Y.H.; Yip, Y.S.; Tan, N.S.; Tan, L.P. Epithelial-mesenchymal transition of cancer cells using bioengineered hybrid scaffold composed of hydrogel/3D-fibrous framework. Sci. Rep. 2019, 9, 8997. [CrossRef]

58. Chaffer, C.L.; Weinberg, R.A. A perspective on cancer cell metastasis. Science 2011, 331, 1559-1564. [CrossRef]

59. Paez, J.G.; Janne, P.A.; Lee, J.C.; Tracy, S.; Greulich, H.; Gabriel, S.; Herman, P.; Kaye, F.J.; Lindeman, N.; Boggon, T.J.; et al. EGFR mutations in lung cancer: Correlation with clinical response to gefitinib therapy. Science 2004, 304, 1497-1500. [CrossRef]

60. Morgillo, F.; Della Corte, C.M.; Fasano, M.; Ciardiello, F. Mechanisms of resistance to EGFR-targeted drugs: Lung cancer. ESMO Open 2016, 1, e000060. [CrossRef] 
61. Le, T.; Gerber, D.E. Newer-Generation EGFR Inhibitors in Lung Cancer: How Are They Best Used? Cancers 2019, 11, 366. [CrossRef] [PubMed]

62. Gainor, J.F.; Dardaei, L.; Yoda, S.; Friboulet, L.; Leshchiner, I.; Katayama, R.; Dagogo-Jack, I.; Gadgeel, S.; Schultz, K.; Singh, M.; et al. Molecular Mechanisms of Resistance to First- and Second-Generation ALK Inhibitors in ALK-Rearranged Lung Cancer. Cancer Discov. 2016, 6, 1118-1133. [CrossRef]

63. Shaw, A.T.; Solomon, B.J.; Besse, B.; Bauer, T.M.; Lin, C.C.; Soo, R.A.; Riely, G.J.; Ou, S.I.; Clancy, J.S.; Li, S.; et al. ALK Resistance Mutations and Efficacy of Lorlatinib in Advanced Anaplastic Lymphoma Kinase-Positive Non-Small-Cell Lung Cancer. J. Clin. Oncol. 2019, 37, 1370-1379. [CrossRef] [PubMed]

64. Kessler, D.; Gmachl, M.; Mantoulidis, A.; Martin, L.J.; Zoephel, A.; Mayer, M.; Gollner, A.; Covini, D.; Fischer, S.; Gerstberger, T.; et al. Drugging an undruggable pocket on KRAS. Proc. Natl. Acad. Sci. USA 2019, 116, 15823-15829. [CrossRef] [PubMed]

65. Kobayashi, S.; Boggon, T.J.; Dayaram, T.; Janne, P.A.; Kocher, O.; Meyerson, M.; Johnson, B.E.; Eck, M.J.; Tenen, D.G.; Halmos, B. EGFR mutation and resistance of non-small-cell lung cancer to gefitinib. N. Engl. J. Med. 2005, 352, 786-792. [CrossRef] [PubMed]

66. Thress, K.S.; Paweletz, C.P.; Felip, E.; Cho, B.C.; Stetson, D.; Dougherty, B.; Lai, Z.; Markovets, A.; Vivancos, A.; Kuang, Y.; et al. Acquired EGFR C797S mutation mediates resistance to AZD9291 in non-small cell lung cancer harboring EGFR T790M. Nat. Med. 2015, 21, 560-562. [CrossRef]

67. Tan, C.S.; Kumarakulasinghe, N.B.; Huang, Y.Q.; Ang, Y.L.E.; Choo, J.R.; Goh, B.C.; Soo, R.A. Third generation EGFR TKIs: Current data and future directions. Mol. Cancer 2018, 17, 29. [CrossRef]

68. Passiglia, F.; Van Der Steen, N.; Raez, L.; Pauwels, P.; Gil-Bazo, I.; Santos, E.; Santini, D.; Tesoriere, G.; Russo, A.; Bronte, G.; et al. The role of cMet in non-small cell lung cancer resistant to EGFR-inhibitors: Did we really find the target? Curr. Drug Targets 2014, 15, 1284-1292. [CrossRef]

69. Wang, Q.; Yang, S.; Wang, K.; Sun, S.-Y. MET inhibitors for targeted therapy of EGFR TKI-resistant lung cancer. J. Hematol. Oncol. 2019, 12, 63. [CrossRef]

70. Choi, Y.L.; Soda, M.; Yamashita, Y.; Ueno, T.; Takashima, J.; Nakajima, T.; Yatabe, Y.; Takeuchi, K.; Hamada, T.; Haruta, H.; et al. EML4-ALK mutations in lung cancer that confer resistance to ALK inhibitors. N. Engl. J. Med. 2010, 363, 1734-1739. [CrossRef]

71. Roman, M.; Baraibar, I.; Lopez, I.; Nadal, E.; Rolfo, C.; Vicent, S.; Gil-Bazo, I. KRAS oncogene in non-small cell lung cancer: Clinical perspectives on the treatment of an old target. Mol. Cancer 2018, 17, 33. [CrossRef]

72. Xue, J.Y.; Zhao, Y.; Aronowitz, J.; Mai, T.T.; Vides, A.; Qeriqi, B.; Kim, D.; Li, C.; de Stanchina, E.; Mazutis, L.; et al. Rapid non-uniform adaptation to conformation-specific KRAS(G12C) inhibition. Nature 2020, 577, 421-425. [CrossRef]

73. Ramirez, M.; Rajaram, S.; Steininger, R.J.; Osipchuk, D.; Roth, M.A.; Morinishi, L.S.; Evans, L.; Ji, W.; Hsu, C.-H.; Thurley, K.; et al. Diverse drug-resistance mechanisms can emerge from drug-tolerant cancer persister cells. Nat. Commun. 2016, 7, 10690. [CrossRef]

74. Sharma, S.V.; Lee, D.Y.; Li, B.; Quinlan, M.P.; Takahashi, F.; Maheswaran, S.; McDermott, U.; Azizian, N.; Zou, L.; Fischbach, M.A.; et al. A chromatin-mediated reversible drug-tolerant state in cancer cell subpopulations. Cell 2010, 141, 69-80. [CrossRef]

75. Hata, A.N.; Niederst, M.J.; Archibald, H.L.; Gomez-Caraballo, M.; Siddiqui, F.M.; Mulvey, H.E.; Maruvka, Y.E.; Ji, F.; Bhang, H.E.; Krishnamurthy Radhakrishna, V.; et al. Tumor cells can follow distinct evolutionary paths to become resistant to epidermal growth factor receptor inhibition. Nat. Med. 2016, 22, 262-269. [CrossRef]

76. Shah, K.N.; Bhatt, R.; Rotow, J.; Rohrberg, J.; Olivas, V.; Wang, V.E.; Hemmati, G.; Martins, M.M.; Maynard, A.; Kuhn, J.; et al. Aurora kinase A drives the evolution of resistance to third-generation EGFR inhibitors in lung cancer. Nat. Med. 2019, 25, 111-118. [CrossRef]

77. Bhaskaran, M.; Mohan, M. MicroRNAs: History, biogenesis, and their evolving role in animal development and disease. Vet. Pathol. 2014, 51, 759-774. [CrossRef]

78. Castro, D.; Moreira, M.; Gouveia, A.M.; Pozza, D.H.; De Mello, R.A. MicroRNAs in lung cancer. Oncotarget 2017, 8, 81679-81685. [CrossRef]

79. Chen, Z.; Lei, T.; Chen, X.; Gu, J.; Huang, J.; Lu, B.; Wang, Z. Long non-coding RNA in lung cancer. Clin. Chim. Acta 2019. [CrossRef]

80. Paraskevopoulou, M.D.; Hatzigeorgiou, A.G. Analyzing MiRNA-LncRNA Interactions. In Long Non-Coding RNAs: Methods and Protocols; Feng, Y., Zhang, L., Eds.; Springer New York: New York, NY, USA, 2016; pp. 271-286. 
81. Barrett, S.P.; Salzman, J. Circular RNAs: Analysis, expression and potential functions. Development 2016, 143, 1838-1847. [CrossRef]

82. Di, X.; Jin, X.; Li, R.; Zhao, M.; Wang, K. CircRNAs and lung cancer: Biomarkers and master regulators. Life Sci. 2019, 220, 177-185. [CrossRef]

83. Zhang, W.C.; Chin, T.M.; Yang, H.; Nga, M.E.; Lunny, D.P.; Lim, E.K.H.; Sun, L.L.; Pang, Y.H.; Leow, Y.N.; Malusay, S.R.Y.; et al. Tumour-initiating cell-specific miR-1246 and miR-1290 expression converge to promote non-small cell lung cancer progression. Nat. Commun. 2016, 7, 11702. [CrossRef]

84. Si, M.; Lang, J. The roles of metallothioneins in carcinogenesis. J. Hematol. Oncol. 2018, 11, 107. [CrossRef]

85. Faversani, A.; Amatori, S.; Augello, C.; Colombo, F.; Porretti, L.; Fanelli, M.; Ferrero, S.; Palleschi, A.; Pelicci, P.G.; Belloni, E.; et al. miR-494-3p is a novel tumor driver of lung carcinogenesis. Oncotarget 2017, 8, 7231-7247. [CrossRef]

86. Yin, R.; Zhang, S.; Wu, Y.; Fan, X.; Jiang, F.; Zhang, Z.; Feng, D.; Guo, X.; Xu, L. microRNA-145 suppresses lung adenocarcinoma-initiating cell proliferation by targeting OCT4. Oncol. Rep. 2011, 25, 1747-1754. [CrossRef]

87. Hua, S.; Xiaotao, X.; Renhua, G.; Yongmei, Y.; Lianke, L.; Wen, G.; Yongqian, S. Reduced miR-31 and let-7 maintain the balance between differentiation and quiescence in lung cancer stem-like side population cells. Biomed. Pharmacother. 2012, 66, 89-97. [CrossRef]

88. Liu, Y.; Luo, F.; Xu, Y.; Wang, B.; Zhao, Y.; Xu, W.; Shi, L.; Lu, X.; Liu, Q. Epithelial-mesenchymal transition and cancer stem cells, mediated by a long non-coding RNA, HOTAIR, are involved in cell malignant transformation induced by cigarette smoke extract. Toxicol. Appl. Pharmacol. 2015, 282, 9-19. [CrossRef]

89. Chen, S.; Zhu, J.; Wang, F.; Guan, Z.; Ge, Y.; Yang, X.; Cai, J. LncRNAs and their role in cancer stem cells. Oncotarget 2017, 8, 110685-110692. [CrossRef]

90. Hatley, M.E.; Patrick, D.M.; Garcia, M.R.; Richardson, J.A.; Bassel-Duby, R.; van Rooij, E.; Olson, E.N. Modulation of K-Ras-dependent lung tumorigenesis by MicroRNA-21. Cancer Cell 2010, 18, 282-293. [CrossRef]

91. Edmonds, M.D.; Boyd, K.L.; Moyo, T.; Mitra, R.; Duszynski, R.; Arrate, M.P.; Chen, X.; Zhao, Z.; Blackwell, T.S.; Andl, T.; et al. MicroRNA-31 initiates lung tumorigenesis and promotes mutant KRAS-driven lung cancer. J. Clin. Invest. 2016, 126, 349-364. [CrossRef]

92. Hayashita, Y.; Osada, H.; Tatematsu, Y.; Yamada, H.; Yanagisawa, K.; Tomida, S.; Yatabe, Y.; Kawahara, K.; Sekido, Y.; Takahashi, T. A polycistronic microRNA cluster, miR-17-92, is overexpressed in human lung cancers and enhances cell proliferation. Cancer Res. 2005, 65, 9628-9632. [CrossRef] [PubMed]

93. Liu, X.-H.; Lu, K.-H.; Wang, K.-M.; Sun, M.; Zhang, E.-B.; Yang, J.-S.; Yin, D.-D.; Liu, Z.-L.; Zhou, J.; Liu, Z.-J.; et al. MicroRNA-196a promotes non-small cell lung cancer cell proliferation and invasion through targeting HOXA5. BMC Cancer 2012, 12, 348. [CrossRef] [PubMed]

94. Liang, C.; Zhang, X.; Wang, H.M.; Liu, X.M.; Zhang, X.J.; Zheng, B.; Qian, G.R.; Ma, Z.L. MicroRNA-18a-5p functions as an oncogene by directly targeting IRF2 in lung cancer. Cell Death Dis. 2017, 8, e2764. [CrossRef] [PubMed]

95. Lo Sardo, F.; Forcato, M.; Sacconi, A.; Capaci, V.; Zanconato, F.; Di Agostino, S.; Del Sal, G.; Pandolfi, P.P.; Strano, S.; Bicciato, S.; et al. MCM7 and its hosted miR-25, 93 and 106b cluster elicit YAP/TAZ oncogenic activity in lung cancer. Carcinogenesis 2017, 38, 64-75. [CrossRef] [PubMed]

96. Li, J.; Yang, S.; Yan, W.; Yang, J.; Qin, Y.-J.; Lin, X.-L.; Xie, R.-Y.; Wang, S.-C.; Jin, W.; Gao, F.; et al. MicroRNA-19 triggers epithelial-mesenchymal transition of lung cancer cells accompanied by growth inhibition. Lab. Investig. 2015, 95, 1056-1070. [CrossRef] [PubMed]

97. Hirono, T.; Jingushi, K.; Nagata, T.; Sato, M.; Minami, K.; Aoki, M.; Takeda, A.H.; Umehara, T.; Egawa, H.; Nakatsuji, Y.; et al. MicroRNA-130b functions as an oncomiRNA in non-small cell lung cancer by targeting tissue inhibitor of metalloproteinase-2. Sci. Rep. 2019, 9, 6956. [CrossRef]

98. Zhou, R.; Zhou, X.; Yin, Z.; Guo, J.; Hu, T.; Jiang, S.; Liu, L.; Dong, X.; Zhang, S.; Wu, G. Tumor invasion and metastasis regulated by microRNA-184 and microRNA-574-5p in small-cell lung cancer. Oncotarget 2015, 6, 44609-44622. [CrossRef]

99. Mao, G.; Liu, Y.; Fang, X.; Liu, Y.; Fang, L.; Lin, L.; Liu, X.; Wang, N. Tumor-derived microRNA-494 promotes angiogenesis in non-small cell lung cancer. Angiogenesis 2015, 18, 373-382. [CrossRef]

100. Garofalo, M.; Romano, G.; Di Leva, G.; Nuovo, G.; Jeon, Y.-J.; Ngankeu, A.; Sun, J.; Lovat, F.; Alder, H.; Condorelli, G.; et al. EGFR and MET receptor tyrosine kinase-altered microRNA expression induces tumorigenesis and gefitinib resistance in lung cancers. Nat. Med. 2011, 18, 74-82. [CrossRef] 
101. Shen, H.; Zhu, F.; Liu, J.; Xu, T.; Pei, D.; Wang, R.; Qian, Y.; Li, Q.; Wang, L.; Shi, Z.; et al. Alteration in Mir-21/PTEN expression modulates gefitinib resistance in non-small cell lung cancer. PLoS ONE 2014, 9, e103305. [CrossRef]

102. Zhang, W.C.; Wells, J.M.; Chow, K.-H.; Huang, H.; Yuan, M.; Saxena, T.; Melnick, M.A.; Politi, K.; Asara, J.M.; Costa, D.B.; et al. miR-147b-mediated TCA cycle dysfunction and pseudohypoxia initiate drug tolerance to EGFR inhibitors in lung adenocarcinoma. Nat. Metab. 2019, 1, 460-474. [CrossRef] [PubMed]

103. Babar, I.A.; Czochor, J.; Steinmetz, A.; Weidhaas, J.B.; Glazer, P.M.; Slack, F.J. Inhibition of hypoxia-induced miR-155 radiosensitizes hypoxic lung cancer cells. Cancer Biol. Ther. 2011, 12, 908-914. [CrossRef] [PubMed]

104. Johnson, S.M.; Grosshans, H.; Shingara, J.; Byrom, M.; Jarvis, R.; Cheng, A.; Labourier, E.; Reinert, K.L.; Brown, D.; Slack, F.J. RAS is regulated by the let-7 microRNA family. Cell 2005, 120, 635-647. [CrossRef]

105. Du, M.; Zhang, Y.; Mao, Y.; Mou, J.; Zhao, J.; Xue, Q.; Wang, D.; Huang, J.; Gao, S.; Gao, Y. MiR-33a suppresses proliferation of NSCLC cells via targeting METTL3 mRNA. Biochem. Biophys. Res. Commun. 2017, 482, 582-589. [CrossRef] [PubMed]

106. Yu, T.; Li, J.; Yan, M.; Liu, L.; Lin, H.; Zhao, F.; Sun, L.; Zhang, Y.; Cui, Y.; Zhang, F.; et al. MicroRNA-193a-3p and -5p suppress the metastasis of human non-small-cell lung cancer by downregulating the ERBB4/PIK3R3/mTOR/S6K2 signaling pathway. Oncogene 2015, 34, 413-423. [CrossRef] [PubMed]

107. Gong, M.; Ma, J.; Guillemette, R.; Zhou, M.; Yang, Y.; Yang, Y.; Hock, J.M.; Yu, X. miR-335 inhibits small cell lung cancer bone metastases via IGF-IR and RANKL pathways. Mol. Cancer Res. 2014, 12, 101-110. [CrossRef] [PubMed]

108. Liu, B.; Peng, X.-C.; Zheng, X.-L.; Wang, J.; Qin, Y.-W. MiR-126 restoration down-regulate VEGF and inhibit the growth of lung cancer cell lines in vitro and in vivo. Lung Cancer 2009, 66, 169-175. [CrossRef]

109. Liu, H.; Chen, Y.; Li, Y.; Li, C.; Qin, T.; Bai, M.; Zhang, Z.; Jia, R.; Su, Y.; Wang, C. miR-195 suppresses metastasis and angiogenesis of squamous cell lung cancer by inhibiting the expression of VEGF. Mol. Med. Rep. 2019, 20, 2625-2632. [CrossRef]

110. Cortez, M.A.; Ivan, C.; Valdecanas, D.; Wang, X.; Peltier, H.J.; Ye, Y.; Araujo, L.; Carbone, D.P.; Shilo, K.; Giri, D.K.; et al. PDL1 Regulation by p53 via miR-34. J. Natl. Cancer Inst. 2016, 108. [CrossRef]

111. Xie, W.B.; Liang, L.H.; Wu, K.G.; Wang, L.X.; He, X.; Song, C.; Wang, Y.Q.; Li, Y.H. MiR-140 Expression Regulates Cell Proliferation and Targets PD-L1 in NSCLC. Cell Physiol. Biochem. 2018, 46, 654-663. [CrossRef]

112. Lv, J.; Qiu, M.; Xia, W.; Liu, C.; Xu, Y.; Wang, J.; Leng, X.; Huang, S.; Zhu, R.; Zhao, M.; et al. High expression of long non-coding RNA SBF2-AS1 promotes proliferation in non-small cell lung cancer. J. Exp. Clin. Cancer Res. 2016, 35, 75. [CrossRef] [PubMed]

113. Peng, Z.; Wang, J.; Shan, B.; Li, B.; Peng, W.; Dong, Y.; Shi, W.; Zhao, W.; He, D.; Duan, M.; et al. The long noncoding RNA LINC00312 induces lung adenocarcinoma migration and vasculogenic mimicry through directly binding YBX1. Mol. Cancer 2018, 17, 167. [CrossRef] [PubMed]

114. Terashima, M.; Tange, S.; Ishimura, A.; Suzuki, T. MEG3 Long Noncoding RNA Contributes to the Epigenetic Regulation of Epithelial-Mesenchymal Transition in Lung Cancer Cell Lines. J. Biol. Chem. 2017, 292, 82-99. [CrossRef]

115. Lin, S.; Zhang, R.; An, X.; Li, Z.; Fang, C.; Pan, B.; Chen, W.; Xu, G.; Han, W. LncRNA HOXA-AS3 confers cisplatin resistance by interacting with HOXA3 in non-small-cell lung carcinoma cells. Oncogenesis 2019, 8, 60. [CrossRef]

116. Hou, Z.; Zhao, W.; Zhou, J.; Shen, L.; Zhan, P.; Xu, C.; Chang, C.; Bi, H.; Zou, J.; Yao, X.; et al. A long noncoding RNA Sox2ot regulates lung cancer cell proliferation and is a prognostic indicator of poor survival. Int. J. Biochem. Cell Biol. 2014, 53, 380-388. [CrossRef] [PubMed]

117. Cui, J.; Mo, J.; Luo, M.; Yu, Q.; Zhou, S.; Li, T.; Zhang, Y.; Luo, W. c-Myc-activated long non-coding RNA H19 downregulates miR-107 and promotes cell cycle progression of non-small cell lung cancer. Int. J. Clin. Exp. Pathol. 2015, 8, 12400-12409.

118. Nie, F.Q.; Sun, M.; Yang, J.S.; Xie, M.; Xu, T.P.; Xia, R.; Liu, Y.W.; Liu, X.H.; Zhang, E.B.; Lu, K.H.; et al. Long noncoding RNA ANRIL promotes non-small cell lung cancer cell proliferation and inhibits apoptosis by silencing KLF2 and P21 expression. Mol. Cancer Ther. 2015, 14, 268-277. [CrossRef]

119. Ge, X.; Li, G.-y.; Jiang, L.; Jia, L.; Zhang, Z.; Li, X.; Wang, R.; Zhou, M.; Zhou, Y.; Zeng, Z.; et al. Long noncoding RNA CAR10 promotes lung adenocarcinoma metastasis via miR-203/30/SNAI axis. Oncogene 2019, 38, 3061-3076. [CrossRef]

120. Li, J.; Wang, J.; Chen, Y.; Li, S.; Jin, M.; Wang, H.; Chen, Z.; Yu, W. LncRNA MALAT1 exerts oncogenic functions in lung adenocarcinoma by targeting miR-204. Am. J. Cancer Res. 2016, 6, 1099-1107. 
121. Wu, D.; Li, Y.; Zhang, H.; Hu, X. Knockdown of Lncrna PVT1 Enhances Radiosensitivity in Non-Small Cell Lung Cancer by Sponging Mir-195. Cell Physiol. Biochem. 2017, 42, 2453-2466. [CrossRef]

122. Pan, H.; Jiang, T.; Cheng, N.; Wang, Q.; Ren, S.; Li, X.; Zhao, C.; Zhang, L.; Cai, W.; Zhou, C. Long non-coding RNA BC087858 induces non-T790M mutation acquired resistance to EGFR-TKIs by activating PI3K/AKT and MEK/ERK pathways and EMT in non-small-cell lung cancer. Oncotarget 2016, 7, 49948-49960. [CrossRef] [PubMed]

123. Hao, Y.; Yang, X.; Zhang, D.; Luo, J.; Chen, R. Long noncoding RNA LINC01186, regulated by TGF- $\beta / S M A D 3$, inhibits migration and invasion through Epithelial-Mesenchymal-Transition in lung cancer. Gene 2017, 608, 1-12. [CrossRef]

124. Wang, H.; Lu, B.; Ren, S.; Wu, F.; Wang, X.; Yan, C.; Wang, Z. Long Noncoding RNA LINC01116 Contributes to Gefitinib Resistance in Non-small Cell Lung Cancer through Regulating IFI44. Mol. Ther. Nucleic Acids 2019, 19, 218-227. [CrossRef]

125. Castellano, J.J.; Navarro, A.; Vinolas, N.; Marrades, R.M.; Moises, J.; Cordeiro, A.; Saco, A.; Munoz, C.; Fuster, D.; Molins, L.; et al. LincRNA-p21 Impacts Prognosis in Resected Non-Small Cell Lung Cancer Patients through Angiogenesis Regulation. J. Thorac. Oncol. 2016, 11, 2173-2182. [CrossRef]

126. Tian, X.; Ma, J.; Wang, T.; Tian, J.; Zhang, Y.; Mao, L.; Xu, H.; Wang, S. Long Non-Coding RNA HOXA Transcript Antisense RNA Myeloid-Specific 1-HOXA1 Axis Downregulates the Immunosuppressive Activity of Myeloid-Derived Suppressor Cells in Lung Cancer. Front. Immunol. 2018, 9, 473. [CrossRef]

127. Han, L.; Zhang, E.b.; Yin, D.d.; Kong, R.; Xu, T.p.; Chen, W.m.; Xia, R.; Shu, Y.q.; De, W. Low expression of long noncoding RNA PANDAR predicts a poor prognosis of non-small cell lung cancer and affects cell apoptosis by regulating Bcl-2. Cell Death Dis. 2015, 6, e1665. [CrossRef] [PubMed]

128. Su, W.; Feng, S.; Chen, X.; Yang, X.; Mao, R.; Guo, C.; Wang, Z.; Thomas, D.G.; Lin, J.; Reddy, R.M.; et al. Silencing of Long Noncoding RNA MIR22HG Triggers Cell Survival/Death Signaling via Oncogenes YBX1, MET, and p21 in Lung Cancer. Cancer Res. 2018, 78, 3207-3219. [CrossRef] [PubMed]

129. Shi, X.; Sun, M.; Liu, H.; Yao, Y.; Kong, R.; Chen, F.; Song, Y. A critical role for the long non-coding RNA GAS5 in proliferation and apoptosis in non-small-cell lung cancer. Mol. Carcinog. 2015, 54, E1-E12. [CrossRef] [PubMed]

130. Dong, S.; Qu, X.; Li, W.; Zhong, X.; Li, P.; Yang, S.; Chen, X.; Shao, M.; Zhang, L. The long non-coding RNA, GAS5, enhances gefitinib-induced cell death in innate EGFR tyrosine kinase inhibitor-resistant lung adenocarcinoma cells with wide-type EGFR via downregulation of the IGF-1R expression. J. Hematol. Oncol. 2015, 8, 43. [CrossRef]

131. Zhang, P.-F.; Pei, X.; Li, K.-S.; Jin, L.-N.; Wang, F.; Wu, J.; Zhang, X.-M. Circular RNA circFGFR1 promotes progression and anti-PD-1 resistance by sponging miR-381-3p in non-small cell lung cancer cells. Mol. Cancer 2019, 18, 179. [CrossRef]

132. Fan, J.; Yin, Z.; Xu, J.; Wu, F.; Huang, Q.; Yang, L.; Jin, Y.; Yang, G. Circulating microRNAs predict the response to anti-PD-1 therapy in non-small cell lung cancer. Genomics 2019. [CrossRef] [PubMed]

133. Qu, D.; Yan, B.; Xin, R.; Ma, T. A novel circular RNA hsa_circ_0020123 exerts oncogenic properties through suppression of miR-144 in non-small cell lung cancer. Am. J. Cancer Res. 2018, 8, 1387-1402.

134. Cheng, Z.; Yu, C.; Cui, S.; Wang, H.; Jin, H.; Wang, C.; Li, B.; Qin, M.; Yang, C.; He, J.; et al. circTP63 functions as a ceRNA to promote lung squamous cell carcinoma progression by upregulating FOXM1. Nat. Commun. 2019, 10, 3200. [CrossRef] [PubMed]

135. Qiu, M.; Xia, W.; Chen, R.; Wang, S.; Xu, Y.; Ma, Z.; Xu, W.; Zhang, E.; Wang, J.; Fang, T.; et al. The Circular RNA circPRKCI Promotes Tumor Growth in Lung Adenocarcinoma. Cancer Res. 2018, 78, 2839-2851. [CrossRef] [PubMed]

136. Luo, Y.H.; Zhu, X.Z.; Huang, K.W.; Zhang, Q.; Fan, Y.X.; Yan, P.W.; Wen, J. Emerging roles of circular RNA hsa_circ_0000064 in the proliferation and metastasis of lung cancer. Biomed. Pharmacother. 2017, 96, 892-898. [CrossRef] [PubMed]

137. Tan, S.; Gou, Q.; Pu, W.; Guo, C.; Yang, Y.; Wu, K.; Liu, Y.; Liu, L.; Wei, Y.-Q.; Peng, Y. Circular RNA F-circEA produced from EML4-ALK fusion gene as a novel liquid biopsy biomarker for non-small cell lung cancer. Cell Res. 2018, 28, 693-695. [CrossRef] [PubMed]

138. Wang, J.; Li, H. CircRNA circ_0067934 silencing inhibits the proliferation, migration and invasion of NSCLC cells and correlates with unfavorable prognosis in NSCLC. Eur. Rev. Med. Pharmacol. Sci. 2018, 22, 3053-3060. [CrossRef] 
139. Zhang, X.; Yang, D.; Wei, Y. Overexpressed CDR1as functions as an oncogene to promote the tumor progression via miR-7 in non-small-cell lung cancer. Onco. Targets Ther. 2018, 11, 3979-3987. [CrossRef]

140. Liu, W.; Ma, W.; Yuan, Y.; Zhang, Y.; Sun, S. Circular RNA hsa_circRNA_103809 promotes lung cancer progression via facilitating ZNF121-dependent MYC expression by sequestering miR-4302. Biochem. Biophys. Res. Commun. 2018, 500, 846-851. [CrossRef]

141. Wan, L.; Zhang, L.; Fan, K.; Cheng, Z.-X.; Sun, Q.-C.; Wang, J.-J. Circular RNA-ITCH Suppresses Lung Cancer Proliferation via Inhibiting the Wnt/ $\beta$-Catenin Pathway. Biomed. Res. Int. 2016, 2016, 1579490. [CrossRef]

142. Chen, D.; Ma, W.; Ke, Z.; Xie, F. CircRNA hsa_circ_100395 regulates miR-1228/TCF21 pathway to inhibit lung cancer progression. Cell Cycle 2018, 17, 2080-2090. [CrossRef] [PubMed]

143. Gu, X.; Wang, G.; Shen, H.; Fei, X. Hsa_circ_0033155: A potential novel biomarker for non-small cell lung cancer. Exp. Ther. Med. 2018, 16, 3220-3226. [CrossRef] [PubMed]

144. Wang, L.; Liu, S.; Mao, Y.; Xu, J.; Yang, S.; Shen, H.; Xu, W.; Fan, W.; Wang, J. CircRNF13 regulates the invasion and metastasis in lung adenocarcinoma by targeting miR-93-5p. Gene 2018,671, 170-177. [CrossRef]

145. Wang, Q.; Li, D.C.; Li, Z.F.; Liu, C.X.; Xiao, Y.M.; Zhang, B.; Li, X.D.; Zhao, J.; Chen, L.P.; Xing, X.M.; et al. Upregulation of miR-27a contributes to the malignant transformation of human bronchial epithelial cells induced by SV40 small T antigen. Oncogene 2011, 30, 3875-3886. [CrossRef] [PubMed]

146. Du, B.; Wang, Z.; Zhang, X.; Feng, S.; Wang, G.; He, J.; Zhang, B. MicroRNA-545 suppresses cell proliferation by targeting cyclin D1 and CDK4 in lung cancer cells. PLoS ONE 2014, 9, e88022. [CrossRef]

147. Shao, Y.; Shen, Y.-Q.; Li, Y.-L.; Liang, C.; Zhang, B.-J.; Lu, S.-D.; He, Y.-Y.; Wang, P.; Sun, Q.-L.; Jin, Y.-X.; et al. Direct repression of the oncogene CDK4 by the tumor suppressor miR-486-5p in non-small cell lung cancer. Oncotarget 2016, 7, 34011-34021. [CrossRef]

148. Li, D.; Li, D.Q.; Liu, D.; Tang, X.J. MiR-613 induces cell cycle arrest by targeting CDK4 in non-small cell lung cancer. Cell Oncol. 2016, 39, 139-147. [CrossRef]

149. Qin, Y.; Zhou, X.; Huang, C.; Li, L.; Liu, H.; Liang, N.; Chen, Y.; Ma, D.; Han, Z.; Xu, X.; et al. Lower miR-340 expression predicts poor prognosis of non-small cell lung cancer and promotes cell proliferation by targeting CDK4. Gene 2018, 675, 278-284. [CrossRef]

150. Feng, H.; Ge, F.; Du, L.; Zhang, Z.; Liu, D. MiR-34b-3p represses cell proliferation, cell cycle progression and cell apoptosis in non-small-cell lung cancer (NSCLC) by targeting CDK4. J. Cell Mol. Med. 2019, 23, 5282-5291. [CrossRef]

151. Esquela-Kerscher, A.; Trang, P.; Wiggins, J.F.; Patrawala, L.; Cheng, A.; Ford, L.; Weidhaas, J.B.; Brown, D.; Bader, A.G.; Slack, F.J. The let-7 microRNA reduces tumor growth in mouse models of lung cancer. Cell Cycle 2008, 7, 759-764. [CrossRef]

152. Bommer, G.T.; Gerin, I.; Feng, Y.; Kaczorowski, A.J.; Kuick, R.; Love, R.E.; Zhai, Y.; Giordano, T.J.; Qin, Z.S.; Moore, B.B.; et al. p53-mediated activation of miRNA34 candidate tumor-suppressor genes. Curr. Biol. 2007, 17, 1298-1307. [CrossRef] [PubMed]

153. Kasinski, A.L.; Slack, F.J. miRNA-34 prevents cancer initiation and progression in a therapeutically resistant K-ras and p53-induced mouse model of lung adenocarcinoma. Cancer Res. 2012, 72, 5576-5587. [CrossRef] [PubMed]

154. Patnaik, S.; Mallick, R.; Kannisto, E.; Sharma, R.; Bshara, W.; Yendamuri, S.; Dhillon, S.S. MiR-205 and MiR-375 microRNA assays to distinguish squamous cell carcinoma from adenocarcinoma in lung cancer biopsies. J. Thorac. Oncol. 2015, 10, 446-453. [CrossRef] [PubMed]

155. Rosenthal, J.J. The emerging role of RNA editing in plasticity. J. Exp. Biol. 2015, 218, 1812-1821. [CrossRef] [PubMed]

156. Nishikura, K. A-to-I editing of coding and non-coding RNAs by ADARs. Nat. Rev. Mol. Cell Biol. 2016, 17, 83-96. [CrossRef]

157. Zhang, W.C.; Slack, F.J. ADARs Edit MicroRNAs to Promote Leukemic Stem Cell Activity. Cell Stem Cell 2016, 19, 141-142. [CrossRef]

158. Ota, H.; Sakurai, M.; Gupta, R.; Valente, L.; Wulff, B.E.; Ariyoshi, K.; Iizasa, H.; Davuluri, R.V.; Nishikura, K. ADAR1 forms a complex with Dicer to promote microRNA processing and RNA-induced gene silencing. Cell 2013, 153, 575-589. [CrossRef]

159. Sharpnack, M.F.; Chen, B.; Aran, D.; Kosti, I.; Sharpnack, D.D.; Carbone, D.P.; Mallick, P.; Huang, K. Global Transcriptome Analysis of RNA Abundance Regulation by ADAR in Lung Adenocarcinoma. EBioMedicine 2018, 27, 167-175. [CrossRef] 
160. Anadón, C.; Guil, S.; Simó-Riudalbas, L.; Moutinho, C.; Setien, F.; Martinez-Cardus, A.; Moran, S.; Villanueva, A.; Calaf, M.; Vidal, A.; et al. Gene amplification-associated overexpression of the RNA editing enzyme ADAR1 enhances human lung tumorigenesis. Oncogene 2015, 35. [CrossRef]

161. Huang, R.S.; Zheng, Y.L.; Zhao, J.; Chun, X. microRNA-381 suppresses the growth and increases cisplatin sensitivity in non-small cell lung cancer cells through inhibition of nuclear factor-kappaB signaling. Biomed. Pharmacother. 2018, 98, 538-544. [CrossRef]

162. Nigita, G.; Distefano, R.; Veneziano, D.; Romano, G.; Rahman, M.; Wang, K.; Pass, H.; Croce, C.M.; Acunzo, M.; Nana-Sinkam, P. Tissue and exosomal miRNA editing in Non-Small Cell Lung Cancer. Sci. Rep. 2018, 8, 10222. [CrossRef] [PubMed]

163. Gong, J.; Liu, C.; Liu, W.; Xiang, Y.; Diao, L.; Guo, A.-Y.; Han, L. LNCediting: A database for functional effects of RNA editing in IncRNAs. Nucleic Acids Res. 2017, 45, D79-D84. [CrossRef] [PubMed]

164. Wu, X.; Sang, L.; Gong, Y. N6-methyladenine RNA modification and cancers. Am. J. Cancer Res. 2018, 8, 1957-1966.

165. Lin, S.; Choe, J.; Du, P.; Triboulet, R.; Gregory, R.I. The m(6)A Methyltransferase METTL3 Promotes Translation in Human Cancer Cells. Mol. Cell 2016, 62, 335-345. [CrossRef]

166. Alarcón, C.R.; Lee, H.; Goodarzi, H.; Halberg, N.; Tavazoie, S.F. N6-methyladenosine marks primary microRNAs for processing. Nature 2015, 519, 482-485. [CrossRef]

167. Choe, J.; Lin, S.; Zhang, W.; Liu, Q.; Wang, L.; Ramirez-Moya, J.; Du, P.; Kim, W.; Tang, S.; Sliz, P.; et al. mRNA circularization by METTL3-eIF3h enhances translation and promotes oncogenesis. Nature 2018, 561, 556-560. [CrossRef] [PubMed]

168. Xiang, J.F.; Yang, Q.; Liu, C.X.; Wu, M.; Chen, L.L.; Yang, L. N(6)-Methyladenosines Modulate A-to-I RNA Editing. Mol. Cell 2018, 69, 126-135. [CrossRef]

169. Waldman, T.; Kinzler, K.W.; Vogelstein, B. p21 is necessary for the p53-mediated G1 arrest in human cancer cells. Cancer Res. 1995, 55, 5187-5190.

170. Zha, W.; Cao, L.; Shen, Y.; Huang, M. Roles of Mir-144-ZFX pathway in growth regulation of non-small-cell lung cancer. PLoS ONE 2013, 8, e74175. [CrossRef]

171. Petrova, Y.I.; Schecterson, L.; Gumbiner, B.M. Roles for E-cadherin cell surface regulation in cancer. Mol. Biol. Cell 2016, 27, 3233-3244. [CrossRef]

172. Singh, M.; Garg, N.; Venugopal, C.; Hallett, R.; Tokar, T.; McFarlane, N.; Mahendram, S.; Bakhshinyan, D.; Manoranjan, B.; Vora, P.; et al. STAT3 pathway regulates lung-derived brain metastasis initiating cell capacity through miR-21 activation. Oncotarget 2015, 6, 27461-27477. [CrossRef] [PubMed]

173. Perumal, E.; So Youn, K.; Sun, S.; Seung-Hyun, J.; Suji, M.; Jieying, L.; Yeun-Jun, C. PTEN inactivation induces epithelial-mesenchymal transition and metastasis by intranuclear translocation of beta-catenin and snail/slug in non-small cell lung carcinoma cells. Lung Cancer 2019, 130, 25-34. [CrossRef] [PubMed]

174. Bremnes, R.M.; Veve, R.; Hirsch, F.R.; Franklin, W.A. The E-cadherin cell-cell adhesion complex and lung cancer invasion, metastasis, and prognosis. Lung Cancer 2002, 36, 115-124. [CrossRef]

175. Blandin Knight, S.; Crosbie, P.A.; Balata, H.; Chudziak, J.; Hussell, T.; Dive, C. Progress and prospects of early detection in lung cancer. Open Biol. 2017, 7, 170070. [CrossRef]

176. Pardoll, D.M. The blockade of immune checkpoints in cancer immunotherapy. Nat. Rev. Cancer 2012, 12, 252-264. [CrossRef] [PubMed]

177. Pu, X.; Wu, L.; Su, D.; Mao, W.; Fang, B. Immunotherapy for non-small cell lung cancers: Biomarkers for predicting responses and strategies to overcome resistance. BMC Cancer 2018, 18, 1082. [CrossRef]

178. Altorki, N.K.; Markowitz, G.J.; Gao, D.; Port, J.L.; Saxena, A.; Stiles, B.; McGraw, T.; Mittal, V. The lung microenvironment: An important regulator of tumour growth and metastasis. Nat. Rev. Cancer 2019, 19, 9-31. [CrossRef]

179. Kim, T.; Veronese, A.; Pichiorri, F.; Lee, T.J.; Jeon, Y.-J.; Volinia, S.; Pineau, P.; Marchio, A.; Palatini, J.; Suh, S.-S.; et al. p53 regulates epithelial-mesenchymal transition through microRNAs targeting ZEB1 and ZEB2. J. Exp. Med. 2011, 208, 875-883. [CrossRef]

180. Chen, L.; Gibbons, D.L.; Goswami, S.; Cortez, M.A.; Ahn, Y.-H.; Byers, L.A.; Zhang, X.; Yi, X.; Dwyer, D.; Lin, W.; et al. Metastasis is regulated via microRNA-200/ZEB1 axis control of tumour cell PD-L1 expression and intratumoral immunosuppression. Nat. Commun. 2014, 5, 5241. [CrossRef] 
181. Muller-Tidow, C.; Metzger, R.; Kugler, K.; Diederichs, S.; Idos, G.; Thomas, M.; Dockhorn-Dworniczak, B.; Schneider, P.M.; Koeffler, H.P.; Berdel, W.E.; et al. Cyclin E is the only cyclin-dependent kinase 2-associated cyclin that predicts metastasis and survival in early stage non-small cell lung cancer. Cancer Res. 2001, 61, 647-653.

182. Fujita, Y.; Yagishita, S.; Hagiwara, K.; Yoshioka, Y.; Kosaka, N.; Takeshita, F.; Fujiwara, T.; Tsuta, K.; Nokihara, H.; Tamura, T.; et al. The clinical relevance of the miR-197/CKS1B/STAT3-mediated PD-L1 network in chemoresistant non-small-cell lung cancer. Mol. Ther. 2015, 23, 717-727. [CrossRef] [PubMed]

183. Boldrini, L.; Giordano, M.; Niccoli, C.; Melfi, F.; Lucchi, M.; Mussi, A.; Fontanini, G. Role of microRNA-33a in regulating the expression of PD-1 in lung adenocarcinoma. Cancer Cell Int. 2017, 17, 105. [CrossRef] [PubMed]

184. Peng, L.; Chen, Z.; Chen, Y.; Wang, X.; Tang, N. MIR155HG is a prognostic biomarker and associated with immune infiltration and immune checkpoint molecules expression in multiple cancers. Cancer Med. 2019, 8, 7161-7173. [CrossRef] [PubMed]

185. Denaro, N.; Merlano, M.C.; Lo Nigro, C. Long noncoding RNAs as regulators of cancer immunity. Mol. Oncol. 2019, 13, 61-73. [CrossRef]

186. Brambilla, E.; Gazdar, A. Pathogenesis of lung cancer signalling pathways: Roadmap for therapies. Eur. Respir. J. 2009, 33, 1485-1497. [CrossRef]

187. Shtivelman, E.; Hensing, T.; Simon, G.R.; Dennis, P.A.; Otterson, G.A.; Bueno, R.; Salgia, R. Molecular pathways and therapeutic targets in lung cancer. Oncotarget 2014, 5, 1392-1433. [CrossRef]

188. Fang, R.; Xiao, T.; Fang, Z.; Sun, Y.; Li, F.; Gao, Y.; Feng, Y.; Li, L.; Wang, Y.; Liu, X.; et al. MicroRNA-143 (miR-143) regulates cancer glycolysis via targeting hexokinase 2 gene. J. Biol. Chem. 2012, 287, 23227-23235. [CrossRef]

189. Lei, W.; Kang, W.; Nan, Y.; Lei, Z.; Zhongdong, L.; Demin, L.; Lei, S.; Hairong, H. The Downregulation of miR-200c Promotes Lactate Dehydrogenase A Expression and Non-Small Cell Lung Cancer Progression. Oncol. Res. Featur. Preclin. Clin. Cancer Ther. 2018, 26, 1015-1022. [CrossRef]

190. Zhai, S.; Zhao, L.; Lin, T.; Wang, W. Downregulation of miR-33b promotes non-small cell lung cancer cell growth through reprogramming glucose metabolism miR-33b regulates non-small cell lung cancer cell growth. J. Cell. Biochem. 2019, 120, 6651-6660. [CrossRef]

191. Li, L.; Liu, H.; Du, L.; Xi, P.; Wang, Q.; Li, Y.; Liu, D. miR-449a Suppresses LDHA-Mediated Glycolysis to Enhance the Sensitivity of Non-Small Cell Lung Cancer Cells to Ionizing Radiation. Oncol. Res. Featur. Preclin. Clin. Cancer Ther. 2018, 26, 547-556. [CrossRef]

192. Chen, H.; Pei, H.; Hu, W.; Ma, J.; Zhang, J.; Mao, W.; Nie, J.; Xu, C.; Li, B.; Hei, T.K.; et al. Long non-coding RNA CRYBG3 regulates glycolysis of lung cancer cells by interacting with lactate dehydrogenase A. J. Cancer 2018, 9, 2580-2588. [CrossRef] [PubMed]

193. Singh, A.; Happel, C.; Manna, S.K.; Acquaah-Mensah, G.; Carrerero, J.; Kumar, S.; Nasipuri, P.; Krausz, K.W.; Wakabayashi, N.; Dewi, R.; et al. Transcription factor NRF2 regulates miR-1 and miR-206 to drive tumorigenesis. J. Clin. Investig. 2013, 123, 2921-2934. [CrossRef] [PubMed]

194. Puisségur, M.P.; Mazure, N.M.; Bertero, T.; Pradelli, L.; Grosso, S.; Robbe-Sermesant, K.; Maurin, T.; Lebrigand, K.; Cardinaud, B.; Hofman, V.; et al. miR-210 is overexpressed in late stages of lung cancer and mediates mitochondrial alterations associated with modulation of HIF-1 activity. Cell Death Differ. 2011, 18, 465-478. [CrossRef]

195. Vohwinkel, C.U.; Lecuona, E.; Sun, H.; Sommer, N.; Vadász, I.; Chandel, N.S.; Sznajder, J.I. Elevated CO(2) levels cause mitochondrial dysfunction and impair cell proliferation. J. Biol. Chem. 2011, 286, 37067-37076. [CrossRef] [PubMed]

196. Li, G.; Li, M.; Hu, J.; Lei, R.; Xiong, H.; Ji, H.; Yin, H.; Wei, Q.; Hu, G. The microRNA-182-PDK4 axis regulates lung tumorigenesis by modulating pyruvate dehydrogenase and lipogenesis. Oncogene 2017, 36, 989-998. [CrossRef] [PubMed]

197. Xin, M.; Qiao, Z.; Li, J.; Liu, J.; Song, S.; Zhao, X.; Miao, P.; Tang, T.; Wang, L.; Liu, W.; et al. miR-22 inhibits tumor growth and metastasis by targeting ATP citrate lyase: Evidence in osteosarcoma, prostate cancer, cervical cancer and lung cancer. Oncotarget 2016, 7, 44252-44265. [CrossRef] [PubMed]

198. Lima Queiroz, A.; Zhang, B.; Comstock, D.E.; Hao, Y.; Eriksson, M.; Hydbring, P.; Vakifahmetoglu-Norberg, H.; Norberg, E. miR-126-5p targets Malate Dehydrogenase 1 in non-small cell lung carcinomas. Biochem. Biophys. Res. Commun. 2018, 499, 314-320. [CrossRef] 
199. Li, Y.L.; Liu, X.M.; Zhang, C.Y.; Zhou, J.B.; Shao, Y.; Liang, C.; Wang, H.M.; Hua, Z.Y.; Lu, S.D.; Ma, Z.L. MicroRNA-34a/EGFR axis plays pivotal roles in lung tumorigenesis. Oncogenesis 2017, 6, e372. [CrossRef]

200. Sun, C.-C.; Li, S.-J.; Zhang, F.; Pan, J.-Y.; Wang, L.; Yang, C.-L.; Xi, Y.-Y.; Li, D.J. Hsa-miR-329 exerts tumor suppressor function through down-regulation of MET in non-small cell lung cancer. Oncotarget 2016, 7, 21510-21526. [CrossRef]

201. Sun, C.; Sang, M.; Li, S.; Sun, X.; Yang, C.; Xi, Y.; Wang, L.; Zhang, F.; Bi, Y.; Fu, Y.; et al. Hsa-miR-139-5p inhibits proliferation and causes apoptosis associated with down-regulation of c-Met. Oncotarget 2015, 6, 39756-39792. [CrossRef]

202. Sun, C.; Liu, Z.; Li, S.; Yang, C.; Xue, R.; Xi, Y.; Wang, L.; Wang, S.; He, Q.; Huang, J.; et al. Down-regulation of c-Met and Bcl2 by microRNA-206, activates apoptosis, and inhibits tumor cell proliferation, migration and colony formation. Oncotarget 2015, 6, 25533-25574. [CrossRef] [PubMed]

203. Xie, Q.; Yu, Z.; Lu, Y.; Fan, J.; Ni, Y.; Ma, L. microRNA-148a-3p inhibited the proliferation and epithelial-mesenchymal transition progression of non-small-cell lung cancer via modulating Ras/MAPK/Erk signaling. J. Cell. Physiol. 2019, 234, 12786-12799. [CrossRef] [PubMed]

204. Seviour, E.G.; Sehgal, V.; Mishra, D.; Rupaimoole, R.; Rodriguez-Aguayo, C.; Lopez-Berestein, G.; Lee, J.S.; Sood, A.K.; Kim, M.P.; Mills, G.B.; et al. Targeting KRas-dependent tumour growth, circulating tumour cells and metastasis in vivo by clinically significant miR-193a-3p. Oncogene 2017, 36, 1339-1350. [CrossRef] [PubMed]

205. Fan, Q.; Hu, X.; Zhang, H.; Wang, S.; Zhang, H.; You, C.; Zhang, C.Y.; Liang, H.; Chen, X.; Ba, Y. MiR-193a-3p is an Important Tumour Suppressor in Lung Cancer and Directly Targets KRAS. Cell. Physiol. Biochem. 2017, 44, 1311-1324. [CrossRef]

206. Ma, Z.; Qiu, X.; Wang, D.; Li, Y.; Zhang, B.; Yuan, T.; Wei, J.; Zhao, B.; Zhao, X.; Lou, J.; et al. MiR-181a-5p inhibits cell proliferation and migration by targeting Kras in non-small cell lung cancer A549 cells. Acta Biochim. Biophys. Sin. 2015, 47, 630-638. [CrossRef]

207. Shi, L.; Middleton, J.; Jeon, Y.-J.; Magee, P.; Veneziano, D.; Laganà, A.; Leong, H.-S.; Sahoo, S.; Fassan, M.; Booton, R.; et al. KRAS induces lung tumorigenesis through microRNAs modulation. Cell Death Dis. 2018, 9 , 219. [CrossRef]

208. Zhang, D.; Zhang, G.; Hu, X.; Wu, L.; Feng, Y.; He, S.; Zhang, Y.; Hu, Z.; Yang, L.; Tian, T.; et al. Oncogenic RAS Regulates Long Noncoding RNA Orilnc1 in Human Cancer. Cancer Res. 2017, 77, 3745-3757. [CrossRef]

209. Cao, X.; Lai, S.; Hu, F.; Li, G.; Wang, G.; Luo, X.; Fu, X.; Hu, J. miR-19a contributes to gefitinib resistance and epithelial mesenchymal transition in non-small cell lung cancer cells by targeting c-Met. Sci. Rep. 2017, 7, 2939. [CrossRef]

210. Wan, L.; Zhu, L.; Xu, J.; Lu, B.; Yang, Y.; Liu, F.; Wang, Z. MicroRNA-409-3p Functions as a Tumor Suppressor in Human Lung Adenocarcinoma by Targeting c-Met. Cell. Physiol. Biochem. 2014, 34, 1273-1290. [CrossRef]

211. Shi, H.; Pu, J.; Zhou, X.-L.; Ning, Y.-Y.; Bai, C. Silencing long non-coding RNA ROR improves sensitivity of non-small-cell lung cancer to cisplatin resistance by inhibiting PI3K/Akt/mTOR signaling pathway. Tumour Biol. 2017, 39, 1010428317697568. [CrossRef]

212. Chen, Y.; Zhou, X.; Qiao, J.; Bao, A. MiR-142-3p Overexpression Increases Chemo-Sensitivity of NSCLC by Inhibiting HMGB1-Mediated Autophagy. Cell. Physiol. Biochem. 2017, 41, 1370-1382. [CrossRef]

213. Wang, N.; Zhu, C.; Xu, Y.; Qian, W.; Zheng, M. Negative Regulation of PTEN by MicroRNA-221 and Its Association with Drug Resistance and Cellular Senescence in Lung Cancer Cells. Biomed. Res. Int. 2018, 1-7. [CrossRef]

214. Zhao, X.; Lu, C.; Chu, W.; Zhang, B.; Zhen, Q.; Wang, R.; Zhang, Y.; Li, Z.; Lv, B.; Li, H.; et al. MicroRNA-124 suppresses proliferation and glycolysis in non-small cell lung cancer cells by targeting AKT-GLUT1/HKII. Tumor Biol. 2017, 39, 1010428317706215. [CrossRef]

215. Wang, M.; Wang, W.; Wang, J.; Zhang, J. MiR-182 promotes glucose metabolism by upregulating hypoxia-inducible factor $1 \alpha$ in NSCLC cells. Biochem. Biophys. Res. Commun. 2018, 504, 400-405. [CrossRef]

216. Chang, L.; Xu, W.; Zhang, Y.; Gong, F. Long non-coding RNA-NEF targets glucose transportation to inhibit the proliferation of non-small-cell lung cancer cells. Oncol Lett 2019, 17, 2795-2801. [CrossRef] [PubMed]

217. Li, J.C.; Zheng, J.Q. Effect of microRNA-145 on proliferation and apoptosis of human non-small cell lung cancer A549 cells by regulating mTOR signaling pathway. J. Cell Biochem. 2017. [CrossRef] [PubMed] 
218. Xi, S.; Xu, H.; Shan, J.; Tao, Y.; Hong, J.A.; Inchauste, S.; Zhang, M.; Kunst, T.F.; Mercedes, L.; Schrump, D.S. Cigarette smoke mediates epigenetic repression of miR-487b during pulmonary carcinogenesis. J. Clin. Investig. 2013, 123, 1241-1261. [CrossRef] [PubMed]

219. Mine, M.; Yamaguchi, K.; Sugiura, T.; Chigita, S.; Yoshihama, N.; Yoshihama, R.; Hiyake, N.; Kobayashi, Y.; Mori, Y. miR-203 Inhibits Frizzled-2 Expression via CD82/KAI1 Expression in Human Lung Carcinoma Cells. PLoS ONE 2015, 10, e0131350. [CrossRef] [PubMed]

220. Wang, Y.; Xia, H.; Zhuang, Z.; Miao, L.; Chen, X.; Cai, H. Axl-altered microRNAs regulate tumorigenicity and gefitinib resistance in lung cancer. Cell Death Dis. 2014, 5, e1227. [CrossRef]

221. Fu, X.; Li, H.; Liu, C.; Hu, B.; Li, T.; Wang, Y. Long noncoding RNA AK126698 inhibits proliferation and migration of non-small cell lung cancer cells by targeting Frizzled-8 and suppressing Wnt/ $\beta$-catenin signaling pathway. Onco. Targets Ther. 2016, 9, 3815-3827. [CrossRef]

222. Guan, H.; Zhu, T.; Wu, S.; Liu, S.; Liu, B.; Wu, J.; Cai, J.; Zhu, X.; Zhang, X.; Zeng, M.; et al. Long noncoding RNA LINC00673-v4 promotes aggressiveness of lung adenocarcinoma via activating WNT/ $\beta$-catenin signaling. Proc. Natl. Acad. Sci. 2019, 116, 14019-14028. [CrossRef] [PubMed]

223. Fortunato, O.; Boeri, M.; Moro, M.; Verri, C.; Mensah, M.; Conte, D.; Caleca, L.; Roz, L.; Pastorino, U.; Sozzi, G. Mir-660 is downregulated in lung cancer patients and its replacement inhibits lung tumorigenesis by targeting MDM2-p53 interaction. Cell Death Dis. 2014, 5, e1564. [CrossRef] [PubMed]

224. Zhang, S.; Zhang, C.; Li, Y.; Wang, P.; Yue, Z.; Xie, S. miR-98 regulates cisplatin-induced A549 cell death by inhibiting TP53 pathway. Biomed. Pharmacother. 2011, 65, 436-442. [CrossRef] [PubMed]

225. Zhang, B.; Chen, M.; Jiang, N.; Shi, K.; Qian, R. A regulatory circuit of circ-MTO1/miR-17/QKI-5 inhibits the proliferation of lung adenocarcinoma. Cancer Biol. Ther. 2019, 20, 1127-1135. [CrossRef] [PubMed]

226. Tai, M.C.; Kajino, T.; Nakatochi, M.; Arima, C.; Shimada, Y.; Suzuki, M.; Miyoshi, H.; Yatabe, Y.; Yanagisawa, K.; Takahashi, T. miR-342-3p regulates MYC transcriptional activity via direct repression of E2F1 in human lung cancer. Carcinogenesis 2015, 36, 1464-1473. [CrossRef] [PubMed]

227. Tao, L.; Shu-Ling, W.; Jing-Bo, H.; Ying, Z.; Rong, H.; Xiang-Qun, L.; Wen-Jie, C.; Lin-Fu, Z. MiR-451a attenuates doxorubicin resistance in lung cancer via suppressing epithelialmesenchymal transition (EMT) through targeting c-Myc. Biomed. Pharmacother. 2020, 125, 109962. [CrossRef]

228. Zhu, D.; Yu, Y.; Wang, W.; Wu, K.; Liu, D.; Yang, Y.; Zhang, C.; Qi, Y.; Zhao, S. Long noncoding RNA PART1 promotes progression of non-small cell lung cancer cells via JAK-STAT signaling pathway. Cancer Med. 2019, 8, 6064-6081. [CrossRef]

229. Wang, N.; Zhang, T. Downregulation of MicroRNA-135 Promotes Sensitivity of Non-Small Cell Lung Cancer to Gefitinib by Targeting TRIM16. Oncol. Res. Featur. Preclin. Clin. Cancer Ther. 2018, 26, 1005-1014. [CrossRef]

230. Wee, P.; Wang, Z. Epidermal Growth Factor Receptor Cell Proliferation Signaling Pathways. Cancers 2017, 9, 52. [CrossRef]

231. Chou, Y.-T.; Lin, H.-H.; Lien, Y.-C.; Wang, Y.-H.; Hong, C.-F.; Kao, Y.-R.; Lin, S.-C.; Chang, Y.-C.; Lin, S.-Y.; Chen, S.-J.; et al. EGFR Promotes Lung Tumorigenesis by Activating miR-7 through a Ras/ERK/Myc Pathway That Targets the Ets2 Transcriptional Repressor ERF. Cancer Res. 2010, 70, 8822-8831. [CrossRef]

232. Seike, M.; Goto, A.; Okano, T.; Bowman, E.D.; Schetter, A.J.; Horikawa, I.; Mathe, E.A.; Jen, J.; Yang, P.; Sugimura, H.; et al. MiR-21 is an EGFR-regulated anti-apoptotic factor in lung cancer in never-smokers. Proc. Natl. Acad. Sci. USA 2009, 106, 12085-12090. [CrossRef] [PubMed]

233. Migliore, C.; Morando, E.; Ghiso, E.; Anastasi, S.; Leoni, V.P.; Apicella, M.; Cora, D.; Sapino, A.; Pietrantonio, F.; De Braud, F.; et al. miR-205 mediates adaptive resistance to MET inhibition via ERRFI1 targeting and raised EGFR signaling. EMBO Mol. Med. 2018, 10, e8746. [CrossRef] [PubMed]

234. Kim, J.H.; Nam, B.; Choi, Y.J.; Kim, S.Y.; Lee, J.-E.; Sung, K.J.; Kim, W.S.; Choi, C.-M.; Chang, E.-J.; Koh, J.S.; et al. Enhanced Glycolysis Supports Cell Survival in EGFR-Mutant Lung Adenocarcinoma by Inhibiting Autophagy-Mediated EGFR Degradation. Cancer Res. 2018, 78, 4482-4496. [CrossRef]

235. Salgia, R. MET in Lung Cancer: Biomarker Selection Based on Scientific Rationale. Mol. Cancer Ther. 2017, 16, 555-565. [CrossRef] [PubMed]

236. Trusolino, L.; Bertotti, A.; Comoglio, P.M. MET signalling: Principles and functions in development, organ regeneration and cancer. Nat. Rev. Mol. Cell Biol. 2010, 11, 834-848. [CrossRef] [PubMed] 
237. Tang, Z.; Du, R.; Jiang, S.; Wu, C.; Barkauskas, D.S.; Richey, J.; Molter, J.; Lam, M.; Flask, C.; Gerson, S.; et al. Dual MET-EGFR combinatorial inhibition against T790M-EGFR-mediated erlotinib-resistant lung cancer. $\mathrm{Br}$. J. Cancer 2008, 99, 911-922. [CrossRef]

238. Suzawa, K.; Offin, M.; Lu, D.; Kurzatkowski, C.; Vojnic, M.; Smith, R.S.; Sabari, J.K.; Tai, H.; Mattar, M.; Khodos, I.; et al. Activation of KRAS Mediates Resistance to Targeted Therapy in MET Exon 14-mutant Non-small Cell Lung Cancer. Clin. Cancer Res. 2019, 25, 1248-1260. [CrossRef]

239. Vanhove, K.; Graulus, G.-J.; Mesotten, L.; Thomeer, M.; Derveaux, E.; Noben, J.-P.; Guedens, W.; Adriaensens, P. The Metabolic Landscape of Lung Cancer: New Insights in a Disturbed Glucose Metabolism. Front. Oncol. 2019, 9, 1215. [CrossRef]

240. Fumarola, C.; Bonelli, M.A.; Petronini, P.G.; Alfieri, R.R. Targeting PI3K/AKT/mTOR pathway in non small cell lung cancer. Biochem. Pharmacol. 2014, 90, 197-207. [CrossRef]

241. Wang, L.; Chen, R.; Zhang, Y. miR-296-3p targets APEX1 to suppress cell migration and invasion of non-small-cell lung cancer. Oncol. Lett. 2019, 18, 2612-2618. [CrossRef]

242. Luo, W.; Lin, Y.; Meng, S.; Guo, Y.; Zhang, J.; Zhang, W. miRNA-296-3p modulates chemosensitivity of lung cancer cells by targeting CX3CR1. Am. J. Transl. Res. 2016, 8, 1848-1856. [PubMed]

243. Xu, T.; Jiang, L.; Wang, Z. The progression of HMGB1-induced autophagy in cancer biology. Onco. Targets Ther. 2018, 12, 365-377. [CrossRef] [PubMed]

244. Cantley, L.C. The Phosphoinositide 3-Kinase Pathway. Science 2002, 296, 1655-1657. [CrossRef]

245. Cai, J.; Fang, L.; Huang, Y.; Li, R.; Yuan, J.; Yang, Y.; Zhu, X.; Chen, B.; Wu, J.; Li, M. miR-205 Targets PTEN and PHLPP2 to Augment AKT Signaling and Drive Malignant Phenotypes in Non-Small Cell Lung Cancer. Cancer Res. 2013, 73, 5402-5415. [CrossRef]

246. Makinoshima, H.; Takita, M.; Saruwatari, K.; Umemura, S.; Obata, Y.; Ishii, G.; Matsumoto, S.; Sugiyama, E.; Ochiai, A.; Abe, R.; et al. Signaling through the Phosphatidylinositol 3-Kinase (PI3K)/Mammalian Target of Rapamycin (mTOR) Axis Is Responsible for Aerobic Glycolysis mediated by Glucose Transporter in Epidermal Growth Factor Receptor (EGFR)-mutated Lung Adenocarcinoma. J. Biol. Chem. 2015, 290, 17495-17504. [CrossRef] [PubMed]

247. Ward, P.S.; Thompson, C.B. Signaling in control of cell growth and metabolism. Cold Spring Harb. Perspect. Biol. 2012, 4, a006783. [CrossRef]

248. Hudson, C.C.; Liu, M.; Chiang, G.G.; Otterness, D.M.; Loomis, D.C.; Kaper, F.; Giaccia, A.J.; Abraham, R.T. Regulation of hypoxia-inducible factor 1alpha expression and function by the mammalian target of rapamycin. Mol. Cell Biol. 2002, 22, 7004-7014. [CrossRef]

249. Peng, X.; Gao, H.; Xu, R.; Wang, H.; Mei, J.; Liu, C. The interplay between HIF-1 $\alpha$ and noncoding RNAs in cancer. J. Exp. Clin. Cancer Res. 2020, 39, 27. [CrossRef]

250. Zhou, C.; Ye, L.; Jiang, C.; Bai, J.; Chi, Y.; Zhang, H. Long noncoding RNA HOTAIR, a hypoxia-inducible factor- $1 \alpha$ activated driver of malignancy, enhances hypoxic cancer cell proliferation, migration, and invasion in non-small cell lung cancer. Tumour Biol. 2015, 36, 9179-9188. [CrossRef]

251. Braicu, C.; Buse, M.; Busuioc, C.; Drula, R.; Gulei, D.; Raduly, L.; Rusu, A.; Irimie, A.; Atanasov, A.G.; Slaby, O.; et al. A Comprehensive Review on MAPK: A Promising Therapeutic Target in Cancer. Cancers 2019, 11, 1618. [CrossRef]

252. Carracedo, A.; Ma, L.; Teruya-Feldstein, J.; Rojo, F.; Salmena, L.; Alimonti, A.; Egia, A.; Sasaki, A.T.; Thomas, G.; Kozma, S.C.; et al. Inhibition of mTORC1 leads to MAPK pathway activation through a PI3K-dependent feedback loop in human cancer. J. Clin. Investig. 2008, 118, 3065-3074. [CrossRef] [PubMed]

253. Liu, P.; Wilson, M.J. miR-520c and miR-373 upregulate MMP9 expression by targeting mTOR and SIRT1, and activate the Ras/Raf/MEK/Erk signaling pathway and NF- $\mathrm{BB}$ factor in human fibrosarcoma cells. J. Cell. Physiol. 2012, 227, 867-876. [CrossRef] [PubMed]

254. Hunter, J.C.; Manandhar, A.; Carrasco, M.A.; Gurbani, D.; Gondi, S.; Westover, K.D. Biochemical and Structural Analysis of Common Cancer-Associated KRAS Mutations. Mol. Cancer Res. 2015, 13, 1325-1335. [CrossRef] [PubMed]

255. Kerr, E.M.; Gaude, E.; Turrell, F.K.; Frezza, C.; Martins, C.P. Mutant Kras copy number defines metabolic reprogramming and therapeutic susceptibilities. Nature 2016, 531, 110-113. [CrossRef]

256. R Babu, K.; Tay, Y. The Yin-Yang Regulation of Reactive Oxygen Species and MicroRNAs in Cancer. Int. J. Mol. Sci. 2019, 20, 5335. [CrossRef] 
257. Zhang, W.C. microRNAs Tune Oxidative Stress in Cancer Therapeutic Tolerance and Resistance. Int. J. Mol. Sci. 2019, 20, 6094. [CrossRef]

258. MacDonald, B.T.; Tamai, K.; He, X. Wnt/beta-catenin signaling: Components, mechanisms, and diseases. Dev. Cell 2009, 17, 9-26. [CrossRef]

259. Stewart, D. Wnt Signaling Pathway in Non-Small Cell Lung Cancer. JNCI 2013, 106. [CrossRef]

260. Xia, Y.; He, Z.; Liu, B.; Wang, P.; Chen, Y. Downregulation of Meg3 enhances cisplatin resistance of lung cancer cells through activation of the WNT/ $\beta$-catenin signaling pathway. Mol. Med. Rep. 2015, 12, 4530-4537. [CrossRef]

261. Liu, J.; Gao, L.; Zhang, H.; Wang, D.; Wang, M.; Zhu, J.; Pang, C.; Wang, C. Succinate dehydrogenase 5 (SDH5) regulates glycogen synthase kinase $3 \beta-\beta$-catenin-mediated lung cancer metastasis. J. Biol. Chem. 2013, 288, 29965-29973. [CrossRef]

262. Funato, Y.; Michiue, T.; Asashima, M.; Miki, H. The thioredoxin-related redox-regulating protein nucleoredoxin inhibits Wnt- $\beta$-catenin signalling through Dishevelled. Nat. Cell Biol. 2006, 8, 501-508. [CrossRef] [PubMed]

263. Rharass, T.; Lemcke, H.; Lantow, M.; Kuznetsov, S.A.; Weiss, D.G.; Panáková, D. Ca2+-mediated mitochondrial reactive oxygen species metabolism augments Wnt/ $\beta$-catenin pathway activation to facilitate cell differentiation. J. Biol. Chem. 2014, 289, 27937-27951. [CrossRef] [PubMed]

264. Chocarro-Calvo, A.; García-Martínez, J.M.; Ardila-González, S.; De la Vieja, A.; García-Jiménez, C. Glucose-induced $\beta$-catenin acetylation enhances Wnt signaling in cancer. Mol. Cell 2013, 49, 474-486. [CrossRef]

265. Wu, Y.-t.; Li, X.; Liu, Z.-1.; Xu, Z.; Dai, W.; Zhang, K.; Wu, J.-s.; Arshad, B.; Wu, K.-n.; Kong, L.-q. Hepatitis B virus reactivation and antiviral prophylaxis during lung cancer chemotherapy: A systematic review and meta-analysis. PLOS ONE 2017, 12, e0179680. [CrossRef] [PubMed]

266. Yao, Z.-H.; Liao, W.-Y.; Ho, C.-C.; Chen, K.-Y.; Shih, J.-Y.; Chen, J.-S.; Lin, Z.-Z.; Lin, C.-C.; Yang, J.C.-H.; $\mathrm{Yu}, \mathrm{C}$.-J. Incidence of hepatitis $\mathrm{B}$ reactivation during epidermal growth factor receptor tyrosine kinase inhibitor treatment in non-small-cell lung cancer patients. Eur. J. Cancer 2019, 117, 107-115. [CrossRef] [PubMed]

267. Dundar, H.Z.; Aksoy, F.; Aksoy, S.A.; Tasar, P.; Ugras, N.; Tunca, B.; Egeli, U.; Cecener, G.; Yerci, O.; Kaya, E. Overexpression of miR-21 Is Associated With Recurrence in Patients With Hepatitis B Virus-Mediated Hepatocellular Carcinoma Undergoing Liver Transplantation. Transplant. Proc. 2019, 51, 1157-1161. [CrossRef]

268. Jin, J.; Tang, S.; Xia, L.; Du, R.; Xie, H.; Song, J.; Fan, R.; Bi, Q.; Chen, Z.; Yang, G.; et al. MicroRNA-501 promotes HBV replication by targeting HBXIP. Biochem. Biophys. Res. Commun. 2013, 430, 1228-1233. [CrossRef]

269. Feng, J.; Yang, G.; Liu, Y.; Gao, Y.; Zhao, M.; Bu, Y.; Yuan, H.; Yuan, Y.; Yun, H.; Sun, M.; et al. LncRNA PCNAP1 modulates hepatitis B virus replication and enhances tumor growth of liver cancer. Theranostics 2019, 9, 5227-5245. [CrossRef]

270. Wang, S.; Qiu, L.; Yan, X.; Jin, W.; Wang, Y.; Chen, L.; Wu, E.; Ye, X.; Gao, G.F.; Wang, F.; et al. Loss of microRNA 122 expression in patients with hepatitis B enhances hepatitis B virus replication through cyclin G1-modulated P53 activity. Hepatology 2012, 55, 730-741. [CrossRef]

271. Yang, X.; Li, H.; Sun, H.; Fan, H.; Hu, Y.; Liu, M.; Li, X.; Tang, H. Hepatitis B Virus-Encoded MicroRNA Controls Viral Replication. J. Virol. 2017, 91, e01919. [CrossRef]

272. Hu, W.; Wang, X.; Ding, X.; Li, Y.; Zhang, X.; Xie, P.; Yang, J.; Wang, S. MicroRNA-141 represses HBV replication by targeting PPARA. PLoS ONE 2012, 7, e34165. [CrossRef]

273. Oura, K.; Fujita, K.; Morishita, A.; Iwama, H.; Nakahara, M.; Tadokoro, T.; Sakamoto, T.; Nomura, T.; Yoneyama, H.; Mimura, S.; et al. Serum microRNA-125a-5p as a potential biomarker of HCV-associated hepatocellular carcinoma. Oncol. Lett. 2019, 18, 882-890. [CrossRef] [PubMed]

274. Wang, G.; Mao, W.; Zheng, S.; Ye, J. Epidermal growth factor receptor-regulated miR-125a-5p-a metastatic inhibitor of lung cancer. FEBS J. 2009, 276, 5571-5578. [CrossRef]

275. Chen, Y.; Chen, J.; Wang, H.; Shi, J.; Wu, K.; Liu, S.; Liu, Y.; Wu, J. HCV-induced miR-21 contributes to evasion of host immune system by targeting MyD88 and IRAK1. PLoS Pathog. 2013, 9, e1003248. [CrossRef] [PubMed] 
276. Hou, W.; Tian, Q.; Zheng, J.; Bonkovsky, H.L. MicroRNA-196 represses Bach1 protein and hepatitis C virus gene expression in human hepatoma cells expressing hepatitis C viral proteins. Hepatology 2010, 51, 1494-1504. [CrossRef] [PubMed]

277. Sarnow, P.; Sagan, S.M. Unraveling the Mysterious Interactions Between Hepatitis C Virus RNA and Liver-Specific MicroRNA-122. Annu. Rev. Virol. 2016, 3, 309-332. [CrossRef]

278. Chen, F.-F.; Yan, J.-J.; Lai, W.-W.; Jin, Y.-T.; Su, I.-J. Epstein-barr virus-associated nonsmall cell lung carcinoma. Cancer 1998, 82, 2334-2342. [CrossRef]

279. Han, A.J.; Xiong, M.; Zong, Y.S. Association of Epstein-Barr Virus With Lymphoepithelioma-Like Carcinoma of the Lung in Southern China. Am. J. Clin. Pathol. 2000, 114, 220-226. [CrossRef]

280. Gómez-Román, J.J.; Martínez, M.N.; Fernández, S.L.; Val-Bernal, J.F. Epstein-Barr virus-associated adenocarcinomas and squamous-cell lung carcinomas. Mod. Pathol. 2009, 22, 530-537. [CrossRef]

281. Wang, S.; Xiong, H.; Yan, S.; Wu, N.; Lu, Z. Identification and Characterization of Epstein-Barr Virus Genomes in Lung Carcinoma Biopsy Samples by Next-Generation Sequencing Technology. Sci. Rep. 2016, 6, 26156. [CrossRef]

282. Kuzembayeva, M.; Hayes, M.; Sugden, B. Multiple functions are mediated by the miRNAs of Epstein-Barr virus. Curr Opin Virol 2014, 7, 61-65. [CrossRef] [PubMed]

283. Skalsky, R.L.; Cullen, B.R. EBV Noncoding RNAs. Curr Top. Microbiol Immunol 2015, 391, 181-217. [CrossRef] [PubMed]

284. Movassagh, M.; Oduor, C.; Forconi, C.; Moormann, A.M.; Bailey, J.A. Sensitive detection of EBV microRNAs across cancer spectrum reveals association with decreased survival in adult acute myelocytic leukemia. Sci. Rep. 2019, 9, 20321. [CrossRef]

285. Koshiol, J.; Gulley, M.L.; Zhao, Y.; Rubagotti, M.; Marincola, F.M.; Rotunno, M.; Tang, W.; Bergen, A.W.; Bertazzi, P.A.; Roy, D.; et al. Epstein-Barr virus microRNAs and lung cancer. Br. J. Cancer 2011, 105, 320-326. [CrossRef] [PubMed]

286. Ho, J.C.-m.; Leung, C.-C. Management of co-existent tuberculosis and lung cancer. Lung Cancer 2018, 122, 83-87. [CrossRef]

287. Abd-El-Fattah, A.A.; Sadik, N.A.H.; Shaker, O.G.; Aboulftouh, M.L. Differential MicroRNAs Expression in Serum of Patients with Lung Cancer, Pulmonary Tuberculosis, and Pneumonia. Cell Biochem. Biophys. 2013, 67, 875-884. [CrossRef]

288. Shen, Y.; Tang, D.; Yao, R.; Wang, M.; Wang, Y.; Yao, Y.; Li, X.; Zhang, H. microRNA expression profiles associated with survival, disease progression, and response to gefitinib in completely resected non-small-cell lung cancer with EGFR mutation. Med. Oncol. 2013, 30, 750. [CrossRef]

289. Shen, H.; Shen, J.; Wang, L.; Shi, Z.; Wang, M.; Jiang, B.-h.; Shu, Y. Low miR-145 expression level is associated with poor pathological differentiation and poor prognosis in non-small cell lung cancer. Biomed. Pharmacother. 2015, 69, 301-305. [CrossRef]

290. Yuxia, M.; Zhennan, T.; Wei, Z. Circulating miR-125b is a novel biomarker for screening non-small-cell lung cancer and predicts poor prognosis. J. Cancer Res. Clin. Oncol. 2012, 138, 2045-2050. [CrossRef]

291. Stenvold, H.; Donnem, T.; Andersen, S.; Al-Saad, S.; Busund, L.-T.; Bremnes, R.M. Stage and tissue-specific prognostic impact of miR-182 in NSCLC. BMC Cancer 2014, 14, 138. [CrossRef]

292. Zaporozhchenko, I.A.; Morozkin, E.S.; Skvortsova, T.E.; Ponomaryova, A.A.; Rykova, E.Y.; Cherdyntseva, N.V.; Polovnikov, E.S.; Pashkovskaya, O.A.; Pokushalov, E.A.; Vlassov, V.V.; et al. Plasma miR-19b and miR-183 as Potential Biomarkers of Lung Cancer. PLoS ONE 2016, 11, e0165261. [CrossRef] [PubMed]

293. Li, N.; Wang, Y.; Liu, X.; Luo, P.; Jing, W.; Zhu, M.; Tu, J. Identification of Circulating Long Noncoding RNA HOTAIR as a Novel Biomarker for Diagnosis and Monitoring of Non-Small Cell Lung Cancer. Technol. Cancer Res. Treat. 2017, 16, 1060-1066. [CrossRef] [PubMed]

294. Li, N.; Feng, X.B.; Tan, Q.; Luo, P.; Jing, W.; Zhu, M.; Liang, C.; Tu, J.; Ning, Y. Identification of Circulating Long Noncoding RNA Linc00152 as a Novel Biomarker for Diagnosis and Monitoring of Non-Small-Cell Lung Cancer. Dis. Markers 2017, 2017, 7439698. [CrossRef] [PubMed]

295. Liang, W.; Lv, T.; Shi, X.; Liu, H.; Zhu, Q.; Zeng, J.; Yang, W.; Yin, J.; Song, Y. Circulating long noncoding RNA GAS5 is a novel biomarker for the diagnosis of nonsmall cell lung cancer. Medicine 2016, 95, e4608. [CrossRef] [PubMed] 
296. Kamel, L.M.; Atef, D.M.; Mackawy, A.M.H.; Shalaby, S.M.; Abdelraheim, N. Circulating long non-coding RNA GAS5 and SOX2OT as potential biomarkers for diagnosis and prognosis of non-small cell lung cancer. Biotechnol. Appl. Biochem. 2019, 66, 634-642. [CrossRef]

297. Kim, J.S.; Kim, E.J.; Lee, S.; Tan, X.; Liu, X.; Park, S.; Kang, K.; Yoon, J.-S.; Ko, Y.H.; Kurie, J.M.; et al. MiR-34a and $\mathrm{miR}-34 \mathrm{~b} / \mathrm{c}$ have distinct effects on the suppression of lung adenocarcinomas. Exp. Mol. Med. 2019, 51, 9. [CrossRef]

298. Ekert, J.E.; Johnson, K.; Strake, B.; Pardinas, J.; Jarantow, S.; Perkinson, R.; Colter, D.C. Three-Dimensional Lung Tumor Microenvironment Modulates Therapeutic Compound Responsiveness In Vitro - Implication for Drug Development. PLoS ONE 2014, 9, e92248. [CrossRef]

299. Kim, M.; Mun, H.; Sung, C.O.; Cho, E.J.; Jeon, H.-J.; Chun, S.-M.; Jung, D.J.; Shin, T.H.; Jeong, G.S.; Kim, D.K.; et al. Patient-derived lung cancer organoids as in vitro cancer models for therapeutic screening. Nat. Commun. 2019, 10, 3991. [CrossRef]

300. Sachs, N.; Papaspyropoulos, A.; Zomer-van Ommen, D.D.; Heo, I.; Böttinger, L.; Klay, D.; Weeber, F.; Huelsz-Prince, G.; Iakobachvili, N.; Amatngalim, G.D.; et al. Long-term expanding human airway organoids for disease modeling. EMBO J. 2019, 38, e100300. [CrossRef]

301. Movia, D.; Bazou, D.; Volkov, Y.; Prina-Mello, A. Multilayered Cultures of NSCLC cells grown at the Air-Liquid Interface allow the efficacy testing of inhaled anti-cancer drugs. Sci. Rep. 2018, 8, 12920. [CrossRef]

302. Rupaimoole, R.; Slack, F.J. MicroRNA therapeutics: Towards a new era for the management of cancer and other diseases. Nat. Rev. Drug Discov. 2017, 16, 203-222. [CrossRef] [PubMed]

303. Beg, M.S.; Brenner, A.J.; Sachdev, J.; Borad, M.; Kang, Y.K.; Stoudemire, J.; Smith, S.; Bader, A.G.; Kim, S.; Hong, D.S. Phase I study of MRX34, a liposomal miR-34a mimic, administered twice weekly in patients with advanced solid tumors. Invest. New Drugs 2017, 35, 180-188. [CrossRef] [PubMed]

304. Van Zandwijk, N.; Pavlakis, N.; Kao, S.C.; Linton, A.; Boyer, M.J.; Clarke, S.; Huynh, Y.; Chrzanowska, A.; Fulham, M.J.; Bailey, D.L.; et al. Safety and activity of microRNA-loaded minicells in patients with recurrent malignant pleural mesothelioma: A first-in-man, phase 1, open-label, dose-escalation study. Lancet Oncol. 2017, 18, 1386-1396. [CrossRef]

305. Berghmans, T.; Ameye, L.; Lafitte, J.-J.; Colinet, B.; Cortot, A.; CsToth, I.; Holbrechts, S.; Lecomte, J.; Mascaux, C.; Meert, A.-P.; et al. Prospective Validation Obtained in a Similar Group of Patients and with Similar High Throughput Biological Tests Failed to Confirm Signatures for Prediction of Response to Chemotherapy and Survival in Advanced NSCLC: A Prospective Study from the European Lung Cancer Working Party. Front. Oncol. 2015, 4, 386. [CrossRef] [PubMed]

306. Berghmans, T.; Ameye, L.; Willems, L.; Paesmans, M.; Mascaux, C.; Lafitte, J.J.; Meert, A.P.; Scherpereel, A.; Cortot, A.B.; Cstoth, I.; et al. Identification of microRNA-based signatures for response and survival for non-small cell lung cancer treated with cisplatin-vinorelbine A ELCWP prospective study. Lung Cancer 2013, 82, 340-345. [CrossRef]

307. Anfossi, S.; Babayan, A.; Pantel, K.; Calin, G.A. Clinical utility of circulating non-coding RNAs-an update. Nat. Rev. Clin. Oncol. 2018, 15, 541-563. [CrossRef] [PubMed]

308. Slack, F.J.; Chinnaiyan, A.M. The Role of Non-coding RNAs in Oncology. Cell 2019, 179, 1033-1055. [CrossRef] [PubMed]

309. Topol, E.J. High-performance medicine: The convergence of human and artificial intelligence. Nat. Med. 2019, 25, 44-56. [CrossRef] [PubMed]

(C) 2020 by the authors. Licensee MDPI, Basel, Switzerland. This article is an open access article distributed under the terms and conditions of the Creative Commons Attribution (CC BY) license (http://creativecommons.org/licenses/by/4.0/). 